\title{
Optimization, Characterization and Thermodynamic Studies on $B$. licheniformis ALW1 Keratinase
}

\author{
A. M. Hashem ${ }^{*}$, A. M. Abdel-Fattah ${ }^{1}$, S. A. Ismail ${ }^{1}$, M. S. El-Gamal' ${ }^{2}$ M. A. \\ Esawy $^{1}$, M. A. Emran ${ }^{1}$ \\ ${ }^{1}$ Chemistry of Natural and Microbial Products Department, National Research \\ Centre, Dokki, Giza, Egypt, postal code 12622. \\ ${ }^{2}$ Botany and Microbiology Department, Faculty of Science (Boys), Al-Azhar \\ University, Cairo, Egypt.
}

\begin{abstract}
PTIMIZATION of $B$. licheniformis ALW1 keratinase was investigated by using a Plackett - Burman design (PBD) and Central Composite Design (CCD). PBD showed that galactose, inoculum size and corn steep liquor were the most effective variables played a role in improving the enzyme productivity $(87.65 \mathrm{U} / \mathrm{mL})$. CCD results recorded an increase in enzyme productivity to about1.4-fold compared to the basal medium $(99.1 \mathrm{U} / \mathrm{mL})$. The optimum activity for the partial purified enzyme was obtained at $\mathrm{pH} 8.5$ and $70^{\circ} \mathrm{C}$. The activation and deactivation energy were calculated to be $25.37 \mathrm{kJmol}^{-1}$ and $73.38 \mathrm{kJmol}^{-1}$ respectively. The half-life time was $1380,690,530$, and $383 \mathrm{~min}$. at $50^{\circ} \mathrm{C}, 55^{\circ} \mathrm{C}, 60^{\circ} \mathrm{C}$ and $65^{\circ} \mathrm{C}$ respectively. Also, $\mathrm{D}$ values were $4600,2300,1769,1277 \mathrm{~min}$. at the same degree respectively. $\Delta G^{\circ}\left(\mathrm{kJmol}^{-1}\right) \mathrm{kept}$ relatively constant between $50-60^{\circ} \mathrm{C}\left(191.49 \mathrm{kJmol}^{-1}-193.31 \mathrm{kJmol}^{-1}\right)$ and noticeably increase at $65^{\circ} \mathrm{C}\left(212.86 \mathrm{kJmol}^{-1}\right) . \Delta H^{\circ}\left(\mathrm{kJmol}^{-1}\right)$ recorded minor decrease by the increase of temperature. Approximately, most of the tested metals ions have stimulation effect in enzyme activity and $\mathrm{MgSO}_{4} \cdot \mathrm{H}_{2} \mathrm{O}$ was the best (146\%). Among all the tested detergents tween 80 retained $97 \%$ of original enzyme activity. DMSO increased the enzyme activity by about $11 \%$, while propanol and acetonitrile reduced the enzyme activity to about $14 \%$ and $10 \%$ respectively. All the reducing agents had a stimulating effect on enzyme activity with variable degrees. The enzyme (980 U) had the ability to hydrolyze $74 \%$ of the feather to nutritional valuable protein.
\end{abstract}

Keywords: Keratinase, B. licheniformis, Partial purification, Thermodynamic, Kinetics.

\section{Introduction}

One of the most popular environmental pollution problems was the slaughterhouse keratinous wastes accumulation. The feather produced from poultry processing industries was common. Utilization of feathers by microbial keratinases is an efficient method for production of valued products (Fig. 1) with green and inexpensive method [1].

Around $60 \%$ of industrial enzymes were recorded to proteases [2,3]. Keratinases as an example of proteases are used widely in cosmetics, prion degradation, detergents and leather industry $[4,5]$.

Production of microbial enzymes was greatly influenced by the medium component and environmental conditions. Optimization of these factors by the classical method (one variable at a time) consumed a lot of time and effort and gave no date for the interaction between variables. Usage of statistical design could effectively increase the enzyme productivity $[6,7]$.

Feather meal is a product of feather improvement by keratinase. It was composed of carbon, nitrogen, sulfer and hydrogen with a percent of 44, 14, 3.2 and 1.4 respectively and the protein content of feather meal was $87 \%$ [8]. It is also contained rare amino acids such as serine, cysteine, arginine, threonine and proline, which makes feather meal suitable source for using as organic fertilizers, feedstuffs or feed supplement $[9,10]$.

Keratinase was produced from a diverse group of microorganisms including fungi, actinomycetes and bacteria. Keratinolytic enzymes from bacteria largely belonged to serine proteases. The metalloprotease was rarely 
found and associated mainly with Gram-negative bacteria $[11,5,12]$.

Designing of efficient and economic bioprocess of enzymes was dependant on the enzyme stability. The thermodynamic study is considered as one of the essential keys to understand the thermal stability of the enzyme and to judge its capability to be used in industrial field $[13,14]$.
The current study presents sequential optimization strategy to improve keratinase production using Bacillus licheniformis ALW1. Partial purification and characterization of the partial pure keratinase were investigated. As there are a few studies about thermodynamic parameters affecting keratin hydrolysis, the study of these parameters is necessary to use the enzyme efficiently in all industrial applications.

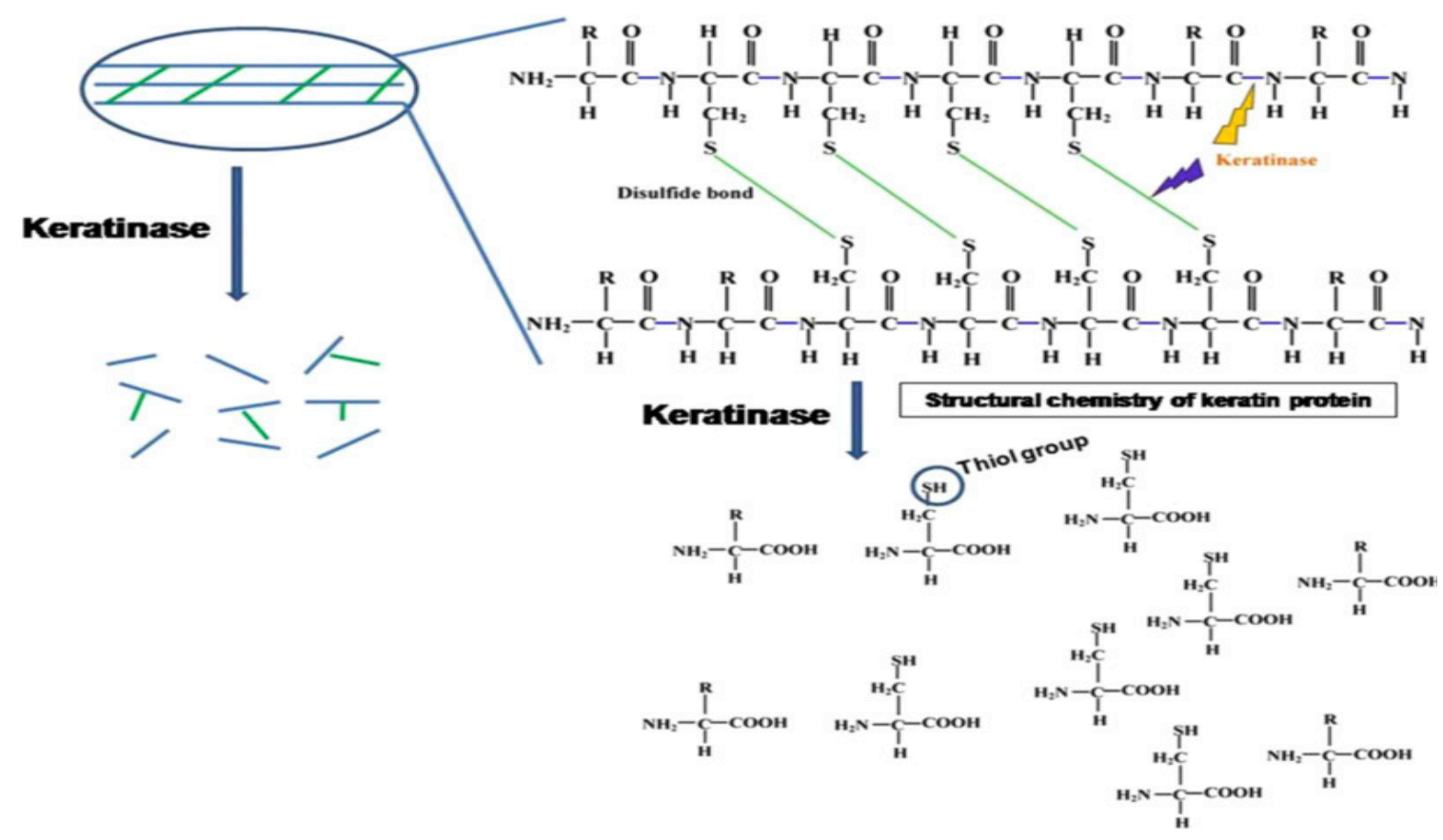

Fig. 1. Schematic representation of keratin and mode of action of keratinolytic enzymes: Source (Paul et al., 2016).

\section{Materials and Methods}

\section{Chemicals}

Turkey feathers were collected from local farm in Kafr Ghataty, Al-Haram, Giza, Egypt. Corn steep liquor (CSL) was obtained from Egyptian Starch and Glucose Company, Mostorod, Qalubia, Egypt. All other chemicals were of analytical grade.

\section{Microorganism}

Bacillus licheniformis ALW1 was identified based on 16s rDNA sequence and Transmission Electron Microscopy examination and It was registered in Gene bank with accession no.

\section{LC315920.}

Feather and soluble keratin preparation

Turkey feathers were prepared for the experiment according to Saber et al. [15]. Soluble

Egypt.J.Chem. 61, No. 4 (2018) keratin was prepared according to the method of Mazotto et al. [5] to be used as the substrate in keratinase assay.

\section{Inoculum preparation}

Ten milliliters of sterilized medium composed of $(\mathrm{g} / \mathrm{L})$ : glucose 10.0 ; peptone 10.0 ; yeast extract 3.0; $\mathrm{CaCl}_{2} .2 \mathrm{H}_{2} \mathrm{O} 2.0 ; \mathrm{pH} 7.0 \pm 0.2$ [16] were added to each slant and scratched with sterile needle. This suspension was transferred to $250 \mathrm{~mL}$ Erlenmeyer flasks containing $40 \mathrm{~mL}$ of sterilized medium, incubated for $48 \mathrm{~h}$ at $37^{\circ} \mathrm{C}$ in shaking incubator at $180 \mathrm{rpm}$.

\section{Fermentation medium}

The production medium contained $1 \%$ native feather which was submerged in $50 \mathrm{~mL}$ medium contained (g/L): $\mathrm{NaCl} 0.5 ; \mathrm{KH}_{2} \mathrm{PO}_{4} 0.7 ; \mathrm{K}_{2} \mathrm{HPO}_{4}$ 1.4; $\mathrm{MgSO}_{4} .7 \mathrm{H}_{2} \mathrm{O} 0.1$; Galactose 1.0; CSL 9.2; pH $6.0 \pm$ 0.2 . The medium was prepared in $250 \mathrm{~mL}$ Erlenmeyer 
flasks, inoculated with $5 \%$ of inoculum medium and incubated at $42^{\circ} \mathrm{C}$ under static condition for four days. At the end of the fermentation period the fermented medium was centrifuged at 5000 rpm for $15 \mathrm{~min}$; the clear supernatant was used for determination of keratinase activity and protein content.

\section{Keratinase assay}

The keratinase activity was assayed by using soluble keratin as substrate according to the method described by Cai et al.[17]. One unit of keratinolytic activity was defined as an increase of $0.01 / \mathrm{min}$ in absorbance at $280 \mathrm{~nm}$ against the blank, under the reaction condition.

\section{Protein determination}

The protein content was determined by the method of Lowry et al. [18] using bovine serum albumin as standard.

\section{Statistical optimization of keratinase production}

The optimization study was performed in two steps started by determination of the effective factors significantly influence keratinase production by using PBD $[19,20]$. In the second step RSM of CCD was performed for prediction of the optimal point of keratinase production. The optimal point was reached by determination the level of three variables significantly increase keratinase production [21, 22].

Plackett - Burman experimental design

The production of keratinase by $B$. licheniformis ALW1 in submerged fermentation was done where seven independent variables were screened in nine combinations organized according to the PBD matrix. For each variable, a high (+) and low (-) level was tested as described in Table 1. PBD was based on the first order linear model (Eq.1):

$$
\mathrm{Y}=\mathrm{B}_{0}+\Sigma \mathrm{B}_{\mathrm{i}} \mathrm{X}_{\mathrm{i}}
$$

Where $\mathrm{Y}$ is the response (keratinase production), $\mathrm{B}_{0}$ is the model intercept and $\mathrm{B}_{\mathrm{i}}$ is the linear coefficient and $X_{i}$ is the level of the independent variable. The main effect of each variable was determined by Eq. (2):

$$
\mathrm{E}_{(\mathrm{Xi})}=2\left(\Sigma \mathrm{M}_{\mathrm{i}+}-\mathrm{M}_{\mathrm{i}-}\right) / \mathrm{N}
$$

Where $\mathrm{E}_{(\mathrm{Xi})}$ was the effect of the tested variable. $\mathrm{M}_{\mathrm{i}+}$ and $\mathrm{M}_{\mathrm{i}-}$ represented keratinase production from the trials where the independent variable (Xi) measured was present at high and low levels respectively and $\mathrm{N}$ is the number of trials. The significance level ( $p$-value) of each tested variable was determined using student's t-test.

TABLE 1. PBD for evaluating factors influencing keratinase production by B. licheniformis ALW1 and the

\begin{tabular}{|c|c|c|c|c|c|c|c|c|c|c|c|}
\hline \multirow{3}{*}{$\begin{array}{c}\text { Trial } \\
1\end{array}$} & \multicolumn{7}{|c|}{ Independent variables } & \multicolumn{4}{|c|}{ Response } \\
\hline & \multirow{2}{*}{$\begin{array}{c}\begin{array}{c}\text { Galactose } \\
(\mathbf{g} / \mathbf{L})\end{array} \\
0.8(-1)\end{array}$} & \multirow{2}{*}{$\begin{array}{l}\begin{array}{l}\text { CSL } \\
(\mathrm{g} / \mathrm{L})\end{array} \\
8(-1)\end{array}$} & \multirow{2}{*}{$\begin{array}{c}\begin{array}{c}\text { Inoculum } \\
\text { size }(\mathbf{m l})\end{array} \\
3(+1)\end{array}$} & \multirow{2}{*}{$\begin{array}{c}\begin{array}{c}\mathbf{N a C l} \\
(\mathrm{g} / \mathrm{L})\end{array} \\
0.6(+1)\end{array}$} & \multirow{2}{*}{$\begin{array}{c}\text { Incubation } \\
\text { period (h) }\end{array}$} & \multirow{2}{*}{$\begin{array}{c}\mathbf{p H} \\
5.5(-1)\end{array}$} & \multirow{2}{*}{$\begin{array}{c}\underset{\mathbf{K}}{\mathbf{K}_{2} \mathbf{H P O}_{4}} \\
1.2(-1)\end{array}$} & \multicolumn{2}{|c|}{$\begin{array}{c}\text { Protein }{ }^{(a)} \\
\text { (mg/ml) }\end{array}$} & \multicolumn{2}{|c|}{$\begin{array}{c}\text { Keratinase }^{(\mathrm{a})} \\
(\mathrm{U} / \mathrm{ml})\end{array}$} \\
\hline & & & & & & & & 2.94 & \pm 0.04 & 80.20 & \pm 2.66 \\
\hline 2 & $1.2(+1)$ & $8(-1)$ & $2(-1)$ & $0.4(-1)$ & $108(+1)$ & $6.5(+1)$ & $1.6(+1)$ & 3.31 & \pm 0.01 & 84.66 & \pm 1.66 \\
\hline 3 & $0.8(-1)$ & $10(+1)$ & $2(-1)$ & $0.6(+1)$ & $84(-1)$ & $6.5(+1)$ & $1.6(+1)$ & 3.64 & \pm 0.04 & 75.85 & \pm 4.11 \\
\hline 4 & $1.2(+1)$ & $10(+1)$ & $3(+1)$ & $0.4(-1)$ & $84(-1)$ & $5.5(-1)$ & $1.2(-1)$ & 2.88 & \pm 0.09 & 87.65 & \pm 2.56 \\
\hline 5 & $0.8(-1)$ & $8(-1)$ & $3(+1)$ & $0.4(-1)$ & $84(-1)$ & $6.5(+1)$ & $1.6(+1)$ & 3.30 & \pm 0.05 & 86.05 & \pm 5.08 \\
\hline 6 & $1.2(+1)$ & $8(-1)$ & $2(-1)$ & $0.6(+1)$ & $84(-1)$ & $5.5(-1)$ & $1.2(-1)$ & 2.64 & \pm 0.06 & 81.16 & \pm 1.68 \\
\hline 7 & $0.8(-1)$ & $10(+1)$ & $2(-1)$ & $0.4(-1)$ & $108(+1)$ & $5.5(-1)$ & $1.2(-1)$ & 3.03 & \pm 0.04 & 70.24 & \pm 7.61 \\
\hline 8 & $1.2(+1)$ & $10(+1)$ & $3(+1)$ & $0.6(+1)$ & $108(+1)$ & $6.5(+1)$ & $1.6(+1)$ & 3.55 & \pm 0.06 & 75.27 & \pm 1.70 \\
\hline $9^{*}$ & $1(0)$ & $9.19(0)$ & $2.5(0)$ & $0.5(0)$ & $96(0)$ & $6(0)$ & $1.4(0)$ & 2.83 & \pm 0.11 & 71.91 & \pm 0.73 \\
\hline $10^{*}$ & $1(0)$ & $9.19(0)$ & $2.5(0)$ & $0.5(0)$ & $96(0)$ & $6(0)$ & $1.4(0)$ & 2.76 & \pm 0.07 & 72.11 & \pm 2.09 \\
\hline $11^{*}$ & $1(0)$ & $9.19(0)$ & $2.5(0)$ & $0.5(0)$ & $96(0)$ & $6(0)$ & $1.4(0)$ & 2.81 & \pm 0.09 & 72.16 & \pm 3.15 \\
\hline
\end{tabular}
observed response.

*Design control, (a) Results are mean \pm SD of three determinations, Numbers in the brackets indicate the code for real values of variables outside the brackets. 
TABLE 2. Statistical analysis of PBD showed the coefficient values, $t$ and $P$ values for each variable on keratinase production.

\begin{tabular}{ccccc}
\hline Variables & \multicolumn{3}{c}{ Keratinase analysis } \\
& Coefficient & $\boldsymbol{t}$-statistics & $\boldsymbol{P}$-value & Confidence level (\%) \\
\hline Intercept & 114.661 & - & - & - \\
Galactose (g/L) & 10.25 & 2.328 & 0.028 & 97.20 \\
Corn steep (g/L) & -3.274 & -3.012 & 0.006 & 99.40 \\
Inoculum size (ml) & 4.315 & 1.975 & 0.059 & 94.10 \\
NaCl conc. $(\mathbf{g} / \mathbf{L})$ & -20.125 & -1.842 & 0.077 & 92.30 \\
Incubation period (h) & -0.212 & -1.877 & 0.072 & 92.80 \\
$\mathbf{K}_{\mathbf{2}} \mathbf{H P O}_{\mathbf{4}}(\mathbf{g} / \mathbf{L})$ & 1.617 & .296 & 0.770 & 23.00 \\
\hline
\end{tabular}

\section{Central Composite Design}

Three variables (Galactose, CSL and Inoculum size) were selected for RSM of CCD. The experimental design consisted of 20 runs and the independent variables were studied at five different levels as shown in Table 3 . The secondorder polynomial function in Eq. (3) was fitted to correlate the relationship between the independent variables and the predicted response $\mathrm{Y}$.

$Y_{\text {Activity }}=\beta_{0}+\beta_{1} X_{1}+\beta_{2} X_{2}+\beta_{3} X_{3}+\beta_{1 I} X_{1}^{2}+\beta_{22} X_{2}^{2}+$ $\beta_{33} X_{3}^{2}+\beta_{12} X_{1} X_{2}+\beta_{13} X_{1} X_{3}+\beta_{23} X_{2} X_{3}$

$\mathrm{Y}_{\text {Activity }}$ is the predicted keratinase production $(\mathrm{U} / \mathrm{mL}), \beta_{0}$ was the model constant, $\mathrm{X}_{1}, \mathrm{X}_{2}$, and $\mathrm{X}_{3}$ (Galactose, CSL and Inoculum size respectively) were the independent variables, $\beta_{1}, \beta_{2}$, and $\beta_{3}$ are the linear coefficients, $\beta_{12}, \beta_{13}$, and $\beta_{23}$ are the cross-product coefficients, and $\beta_{11}, \beta_{22}$, and $\beta_{33}$ are the quadratic coefficients. 'SPSS' Version 15.0 was used for the regression analysis of the experimental data obtained. The fit quality of the polynomial model equation was expressed by a coefficient of determination, $\mathrm{R}^{2}$. The experiments were performed in triplicate and the mean values were recorded.

The quadratic models were represented as $3 \mathrm{D}$ response surface curves generated by using MATLAB version 14 after using Newton method to find the location of the equation maximum.

Partial purification and enzyme protein detection by SDS-PAGE

The culture filtrate was centrifuged (5000 $\mathrm{rpm}$ at $4^{\circ} \mathrm{C}$ for $10 \mathrm{~min}$.) and fractionated with acetone (20-90\%). The precipitate was collected by centrifugation at $10,000 \mathrm{rpm}$ for $10 \mathrm{~min}$. and dissolved in distilled water.

Sodium dodecyl sulfate - polyacrylamide gel electrophoresis was performed according to Laemmli [23] for the crude and partial pure keratinase along with pre-stained molecular weight protein marker (11-250 kDa - FERMENTAS). Electrophoresis was applied to $12 \%(\mathrm{w} / \mathrm{v})$ SDSpolyacrylamide gel at $25 \mathrm{~mA}$ in $1 \mathrm{X}$ Tris/glycineSDS-running buffer. The gel was fixed and stained with Coomassie brilliant blueR-250. After destaining, the gel was dried on gel drier for $2 \mathrm{hrs}$ and photographed.

\section{Properties of partial pure keratinase} Effect of temperature and $\mathrm{pH}$

The optimum temperature of partial pure keratinase was investigated under standard keratinase assay condition by incubating the reaction mixture at a temperature range from $40^{\circ} \mathrm{C}$ to $80^{\circ} \mathrm{C}$ for $15 \mathrm{~min}$. The optimum $\mathrm{pH}$ was determined by incubating the reaction mixture at different $\mathrm{pH}$ values using $0.1 \mathrm{~N}$ tris - $\mathrm{HCl}$ buffer in the range of 7.0 to 9.0 for $15 \mathrm{~min}$. at optimum temperature.

The activation energy (Ea) of catalysis was determined from the slope of the Arrhenius plot [ $\log \mathrm{V}$ (logarithm of \% residual activity) versus reciprocal of absolute temperature in Kelvin $(1000 / \mathrm{T})]$, which is given by the following equation (Eq. 4) where $\mathrm{R}$ is the gas constant $\left(8.314 \mathrm{~mol}^{-1} \mathrm{k}^{-1}\right)$.

Slope $=-\mathrm{Ea} \mathrm{R}$ 
TABLE 3. Examined concentration of the key variables and results of CCD experiment.

\begin{tabular}{|c|c|c|c|c|c|c|c|c|}
\hline \multirow{3}{*}{ 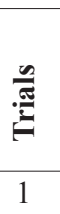 } & \multicolumn{3}{|c|}{ Independent variable } & \multicolumn{4}{|c|}{ Observed response } & \multirow{3}{*}{$\begin{array}{c}\begin{array}{c}\text { Predicted } \\
\text { Keratinase } \\
(\mathbf{U} / \mathbf{m l})\end{array} \\
80.81\end{array}$} \\
\hline & \multirow{2}{*}{$\begin{array}{c}\begin{array}{c}\mathbf{X}_{1} \\
\text { Galactose } \\
(\mathrm{g} / \mathrm{L})\end{array} \\
1.1(-1)\end{array}$} & \multirow{2}{*}{$\begin{array}{c}\begin{array}{c}\text { X2 } \\
\text { Corn steep } \\
\text { (g/L) }\end{array} \\
8(-1)\end{array}$} & \multirow{2}{*}{$\begin{array}{c}\mathbf{X}_{3} \\
\begin{array}{c}\text { Inoculum size } \\
(\mathbf{m l})\end{array} \\
2.5(-1)\end{array}$} & \multicolumn{2}{|c|}{$\begin{array}{c}\operatorname{Protein}^{(a)}(\mathrm{mg} / \\
\mathrm{ml})\end{array}$} & \multicolumn{2}{|c|}{$\begin{array}{c}\text { Keratinase }^{(\mathrm{a})} \\
(\mathrm{U} / \mathrm{ml})\end{array}$} & \\
\hline & & & & 2.87 & \pm 0.13 & 82.52 & \pm 2.27 & \\
\hline 2 & $1.3(+1)$ & $8(-1)$ & $2.5(-1)$ & 2.86 & \pm 0.20 & 79.61 & \pm 2.06 & 83.09 \\
\hline 3 & $1.1(-1)$ & $12(+1)$ & $2.5(-1)$ & 3.00 & \pm 0.16 & 75.66 & \pm 3.33 & 79.32 \\
\hline 4 & $1.3(+1)$ & $12(+1)$ & $2.5(-1)$ & 3.12 & \pm 0.05 & 76.77 & \pm 3.03 & 68.64 \\
\hline 5 & $1.1(-1)$ & $8(-1)$ & $3.5(+1)$ & 2.73 & \pm 0.04 & 75.27 & \pm 3.54 & 79.54 \\
\hline 6 & $1.3(+1)$ & $8(-1)$ & $3.5(+1)$ & 2.87 & \pm 0.08 & 99.11 & \pm 2.61 & 91.60 \\
\hline 7 & $1.1(-1)$ & $12(+1)$ & $3.5(+1)$ & 2.97 & \pm 0.03 & 84.66 & \pm 2.94 & 77.33 \\
\hline 8 & $1.3(+1)$ & $12(+1)$ & $3.5(+1)$ & 3.12 & \pm 0.05 & 85.58 & \pm 2.08 & 83.45 \\
\hline 9 & $1.0(-2)$ & $10(0)$ & $3(0)$ & 2.89 & \pm 0.03 & 83.41 & \pm 3.83 & 82.00 \\
\hline 10 & $1.4(+2)$ & $10(0)$ & $3(0)$ & 2.75 & \pm 0.17 & 84.43 & \pm 3.61 & 89.80 \\
\hline 11 & $1.2(0)$ & $6(-2)$ & $3(0)$ & 2.92 & \pm 0.15 & 76.83 & \pm 1.29 & 75.60 \\
\hline 12 & $1.2(0)$ & $14(+2)$ & $3(0)$ & 3.07 & \pm 0.11 & 60.01 & \pm 2.98 & 65.19 \\
\hline 13 & $1.2(0)$ & $10(0)$ & $2(-2)$ & 3.05 & \pm 0.08 & 74.75 & \pm 2.29 & 74.17 \\
\hline 14 & $1.2(0)$ & $10(0)$ & $4(+2)$ & 2.84 & \pm 0.07 & 81.84 & \pm 2.27 & 86.39 \\
\hline $15^{*}$ & $1.2(0)$ & $10(0)$ & $3(0)$ & 3.07 & \pm 0.20 & 87.47 & \pm 0.79 & 88.28 \\
\hline $16^{*}$ & $1.2(0)$ & $10(0)$ & $3(0)$ & 3.14 & \pm 0.12 & 86.75 & \pm 0.83 & 88.27 \\
\hline $17^{*}$ & $1.2(0)$ & $10(0)$ & $3(0)$ & 3.12 & \pm 0.04 & 86.27 & \pm 1.40 & 88.28 \\
\hline $18^{*}$ & $1.2(0)$ & $10(0)$ & $3(0)$ & 3.07 & \pm 0.20 & 87.10 & \pm 0.29 & 88.28 \\
\hline $19^{*}$ & $1.2(0)$ & $10(0)$ & $3(0)$ & 3.14 & \pm 0.12 & 86.75 & \pm 0.83 & 88.29 \\
\hline $20^{*}$ & $1.2(0)$ & $10(0)$ & $3(0)$ & 3.12 & \pm 0.04 & 86.27 & \pm 1.40 & 88.28 \\
\hline
\end{tabular}

*Design control, (a) Results are mean \pm SD of three determinations, Numbers in the brackets indicate the code for real values of variables outside the brackets.

\section{Effect of substrate concentration}

The enzyme activity with different soluble keratin concentrations $(0.4,0.5,0.6,0.7$ and $0.8 \%$ ) was estimated at the optimal $\mathrm{pH}$ and temperature of the tested partial pure enzyme. The maximum reaction velocity $\left(V_{\max }\right)$, MichaelisMenten constant $\left(K_{m}\right)$, specificity constant $\left(V_{\text {max }}\right.$ ' $K_{m}$ ) were calculated from Lineweaver Bulk plot equation (Eq. 5). The reaction velocity $(V)$ is the specific activity represented in $\mathrm{U} / \mathrm{mg}$ protein, $(S)$ is thesoluble keratin concentrations $(\mathrm{mg} / \mathrm{mL})$.

$\bar{V}=\frac{K m}{V \max } * \frac{1}{S}+\frac{1}{V \max }$

Determination of thermal stability

Thermal stability of the partial pure keratinase was carried out by preheating the enzyme in the absence of substrate at different temperature (50$\left.65^{\circ} \mathrm{C}\right)$ for different time intervals $(15,30,45$, $60,90,120 \mathrm{~min}$.). The residual activities of heat exposed enzymes were then measured under the optimum conditions.

Thermodynamic studies

The $k_{d}$ was estimated by regression plot of $\log$ relative activity (\%) versus time (min). The $t_{1 / 2}$ (the time it takes for the activity to reduce to a half of the original activity) and $D$-value (the time need to reduce $90 \%$ of enzyme activity) for the Bacillus licheniformis ALW1 keratinase was determined from the Eq. $(6,7)$.

$t_{\frac{1}{2}}=\frac{\ln 2}{k_{d}}$

$D-$ value $=\frac{\ln 10}{k_{d}}$

The activation energy $\left(E_{d}\right)$ for Bacillus licheniformis ALW1 keratinase denaturation was determined by a plot of log denaturation rate constants $\left(\ln k_{d}\right)$ versus reciprocal of the absolute temperature (K) using the Eq. (8)

Slope $=-\frac{E_{d}}{R}$

The ${ }^{R}$ change in enthalpy $\left(\Delta H^{\circ}, \mathrm{kJ} \mathrm{mol}^{-1}\right)$, free energy $\left(\Delta G^{\circ}, \mathrm{kJ} \mathrm{mol}^{-1}\right)$ and entropy $\left(\Delta S^{\circ}\right.$, J $\mathrm{mol}^{-1} \mathrm{~K}^{-1}$ ) for thermal denaturation of Bacillus licheniformis ALW1 keratinase was determined using the following Eq. (9, 10 and 11) 


$$
\Delta H^{\circ}=E_{d}-R T
$$

$\Delta G^{0}=-R T \ln \left(\frac{k_{d} \cdot h}{k_{B} \cdot T}\right)$

$\Delta S^{\circ}=\frac{\Delta H^{0}-\Delta G^{\circ}}{T}$

Where $T$ is the corresponding absolute temperature $(\mathrm{K}), R$ is the gas constant $\left(8.314 \mathrm{~J} \mathrm{~mol}^{-1} \mathrm{~K}^{-1}\right), h$ is the Planck constant $\left(11.04 \times 10^{-36} \mathrm{~J} \mathrm{~min}\right)$, and $k_{B}$ is the Boltzman constant $\left(1.38 \times 10^{-23} \mathrm{~J} \mathrm{~K}^{-1}\right)$.

Effect of various inhibitors, reducing agents, detergents, organic solvents and metal ions on keratinase activity

The effect of inhibitors [phenyl methyl sulfonyl fluoride (PMSF) as serine protease inhibitor and ethylene diamine tetraacetic acid (EDTA) as metallo protease inhibitor], reducing agents [2-mercaptoethanol (2-ME), cysteine and sodium sulfite], organic solvents [propanol, dimethyl sulfoxide and acetonitrile], various monovalent metal ions $[\mathrm{NaCl}, \mathrm{KCl}$ and $\left.\mathrm{LiSO}_{4} \cdot \mathrm{H}_{2} \mathrm{O}\right]$ and divalent metal ions $\left[\mathrm{ZnCl}_{2}\right.$, $\mathrm{MgSO}_{4} \cdot \mathrm{H}_{2} \mathrm{O}, \mathrm{CuCl}_{2} \cdot 2 \mathrm{H}_{2} \mathrm{O}, \mathrm{CoCl}_{2} \cdot 6 \mathrm{H}_{2} \mathrm{O}, \mathrm{CaCl}_{2}$, $\mathrm{BaCl}_{2} \cdot 2 \mathrm{H}_{2} \mathrm{O}, \mathrm{HgCl}_{2}$ and $\left.\mathrm{MnCl}_{2} \cdot 2 \mathrm{H}_{2} \mathrm{O}\right]$ at $5 \mathrm{mM}$ were investigated by pre-incubating the partial pure enzyme for $30 \mathrm{~min}$ at room temperature with each item. Keratinase activity was carried out under standard assay conditions and the activity measured as residual activity of the control $(100 \%)$ which is measured in the absence of any tested agents.

Feather degradation by cell free crude keratinase:

Feather $(1.0 \mathrm{~g})$ was autoclaved at $15 \mathrm{psi}$, $121^{\circ} \mathrm{C}$ for $15 \mathrm{~min}$ in a $100 \mathrm{~mL}$ flask containing $15 \mathrm{~mL}, 0.1 \mathrm{M}$ phosphate buffer $\mathrm{pH}$ 8.0. Volume was completed to $20 \mathrm{~mL}$ with crude enzyme to final concentrations of $180,280,380,480$, 580, 680, 780, 880 and $980 \mathrm{U} /$ flask). Flasks were kept at $150 \mathrm{rpm}$ and $50^{\circ} \mathrm{C}$ for $24 \mathrm{~h}$. At the end of the degradation period, feather meal was filtered through $2 \mathrm{~mm}$ sieve and residual feather was dried at $80^{\circ} \mathrm{C}$ until constant weight. Degradation percent was calculated on the basis of dry weight of residual feather. Feather meal suspension was centrifuged at $5000 \times \mathrm{g}$ for 15 min and the remaining keratinase activity (\%) and total protein $(\mathrm{mg} / \mathrm{g}$ feather) were calculated [8]. Experiments were set up in triplicate and the results were represented as mean of three independent experiments.

\section{$\underline{\text { Results and Discussion }}$}

Enzyme production and statistical optimization using $P B D$

Among large number of culture conditions and medium composition, variables largely affecting keratinase production were determined using PBD. Nine combination matrix of seven independent variables for keratinase production were presented in Table 1. The keratinase production yield increased from 70.24 to 87.65 $\mathrm{U} / \mathrm{mL}$ and the optimum yield was obtained by using combination number 4 in Table 1. Variables main effect was shown in Fig.2 and indicated that galactose, inoculum size, $\mathrm{pH}$ and $\mathrm{K}_{2} \mathrm{HPO}_{4}$ had positive main effect while CSL, $\mathrm{NaCl}$ and incubation period had negative main effect.

The regression coefficients, t-test and $\mathrm{p}$-value of seven independent variables in Table 2 indicated $p$-values of $0.006,0.028$ and 0.059 for CSL, galactose and inoculum size respectively. These results make CSL, galactose and inoculum size the most significant variables affecting the keratinase production. Similar data were reported by Sivakumar et al. [24]; they found that galactose had a fundamental role in increasing the Chryseobacterium sp. keratinase productivity. CSL is a rich source of proteins, vitamins and minerals and expected to be a good medium for production of Bacillus Licheniformis ZJUEL31410 keratinase[25]. Jani et al. [26] reported that inoculum size was an important factor in Bacillus sp. B13 keratinase production.

The correlation between independent variables and keratinase production could be presented by first order model Eq. (12):

$Y_{\text {Activity }}=114.661+10.25 X_{1}-3.274 X_{2}+4.315 X_{3}$ $20.125 X_{4}-0.212 X_{5}+1.617 X_{6}$

\section{Central Composite Design}

Statistical and mathematical analysis of multivariable data obtained from RSM of CCD was very important in improving and optimization of keratinase production by $B$. licheniformis ALW1. The medium composed of $(\mathrm{g} / \mathrm{L})$ : feather $10 ; \mathrm{NaCl}$ $0.4 ; \mathrm{KH}_{2} \mathrm{PO}_{4} 0.7 ; \mathrm{K}_{2} \mathrm{HPO}_{4} 1.2 ; \mathrm{MgSO}_{4} .7 \mathrm{H}_{2} \mathrm{O} 0.1$; Galactose 1.2; CSL10.0; pH $5.5 \pm 0.2$; inoculated with $6 \%$ of inoculum medium and incubated at $42^{\circ} \mathrm{C}$ under static condition was used as the central point of the CCD. Twenty trials matrix of CCD with three factors obtained from PBD (galactose, CSL and inoculum size) and five levels (-2, -1, 0 , 
+1 and +2 ) including six replicates at the central point were represented in Table 3. A second order polynomial equation (Eq. 13) was obtained by multiple regression analysis of observed data and the mathematical optimal point of equation was determined by Newton method using MATLAB version 14.

$Y_{\text {Activity }}=-104.974+102.499 X_{1}+33.48 X_{2}-30.624 X_{3}-$ $70.015 X_{1}^{2}-1.144 X_{2}^{2} \quad-8.422 X_{3}^{2}-11.813 X_{1} X_{2}+$ $66.433 X_{1} X_{3}+0.697 X_{2} X_{3}$

Where response $\left(Y_{\text {Activity }}\right)$ was predicted keratinase production and $\left(\mathrm{X}_{1}, \mathrm{X}_{2}\right.$ and $\left.\mathrm{X}_{3}\right)$ were the codes of most effective variables galactose, CSLand inoculum size respectively. The mathematical optimal point of the equation was $101.14 \mathrm{U} / \mathrm{mL}$ at $1.4,8.6 \mathrm{gm} / \mathrm{L}$ of galactose and CSL respectively with $4 \mathrm{~mL} /$ flask inoculum size. Our result was superior than that of Ni et al. [25]. They used RSM to optimize $B$. licheniformis ZJUEL31410 keratinase production under submerged fermentation to reach $54.9 \mathrm{U} / \mathrm{mL}$ under the optimal fermentation condition. Three dimensional graphs of the regression equation (Fig. $3 \mathrm{~A}-\mathrm{C}$ ) explained main and interaction effects of galactose and CSL; galactose and inoculum size; CSL and inoculum size on keratinase production by $B$. licheniformis ALW1 respectively, when the third variable was kept at the value which gave the optimum point of the equation.

The $P$-value was used as a tool to check significant of each coefficient which in turn indicate the pattern of the interaction between the variables [27]. The statistical analysis of data (Table 4) indicated high significant effect of terms with smaller $P$-values $(P<0.05)$ on keratinase production.

\section{Validation of the model}

The validity of the proposed model was estimated by prediction of $B$. licheniformis ALW1 keratinase production for each trial of the matrix. The experimental results in Table 3 showed that the maximum observed keratinase production $(99.1 \mathrm{U} / \mathrm{mL})$ was very close to the predicted value $(91.6 \mathrm{U} / \mathrm{mL})$. The model $P$ and F-values were equal to 0.0001 and 20.923 respectively and $\mathrm{R}^{2}$ (determination of coefficient) was found to be $79 \%$ indicated that the model equation could explain the response variability. Thus, the second-order polynomial equation (Eq. 13) could be used to identify the relation between the three variables (Galactose, CSL, Inoculum size) and the keratinase production. The optimum keratinase production reached $99.1 \mathrm{U} / \mathrm{mL}$ which represented 1.4 fold increases with respect to the basal medium.

Partial purification and enzyme protein detection by SDS-PAGE

The $B$. licheniformis ALW1 crude keratinase was partially purified at $60-70 \%$ acetone fraction with a specific activity of $785.6 \mathrm{U} / \mathrm{mg}$ with 24.9 fold of purification. Saibabu et al. [28] and Tiwary and Gupta [29] mentioned acetone as the best solvent for the partial purification of keratinase from Bacillus sp.

SDS-PAGE results (Fig.4) indicated multiple protein bands in crude and partial pure culture filtrate of $B$. licheniformis ALW1. Partial purification processes resulted on remove of some protein bands and increase the intensity of some other bands. Bands at Rfs 0.423, 0.576 and 0.696 (Mwts 59.2, 27.4 and $17.2 \mathrm{kDa}$, respectively) appeared in partial pure keratinase lane. However, the majority of keratinases presented molecular masses varying from $30-50 \mathrm{kDa}$ [30]. On the other hand a small molecular mass $(18 \mathrm{kDa})$ was also reported for Streptomyces albidoflavus [31].

TABLE 4. Analysis of CCD for keratinase production by B. licheniformis ALW1.

\begin{tabular}{ccccc}
\hline Term & Regression coefficient & Standard error & $\boldsymbol{t}$ - test & \multicolumn{2}{c}{$\boldsymbol{P}$-value } \\
Intercept & -104.974 & 110.091 & -0.954 & 0.345 \\
\hline $\boldsymbol{X}_{\boldsymbol{I}}$ & 102.499 & 127.783 & 0.802 & 0.426 \\
$\boldsymbol{X}_{2}$ & 33.48 & 5.951 & 5.626 & 0.000 \\
$\boldsymbol{X}_{3}$ & -30.624 & 23.97 & -1.278 & 0.207 \\
$\boldsymbol{X}_{1}^{2}$ & -70.015 & 46.071 & -1.520 & 0.135 \\
$\boldsymbol{X}_{2}^{2}$ & -1.144 & 0.115 & -9.931 & 0.000 \\
$\boldsymbol{X}_{3}^{2}$ & -8.422 & 1.843 & -4.570 & 0.000 \\
$\boldsymbol{X}_{I} \boldsymbol{X}_{2}$ & -11.813 & 4.084 & -2.893 & 0.006 \\
$\boldsymbol{X}_{I} \boldsymbol{X}_{3}$ & 66.433 & 16.335 & 4.067 & 0.000 \\
$\boldsymbol{X}_{2} \boldsymbol{X}_{3}$ & 0.697 & 0.817 & 0.853 & 0.398 \\
\hline
\end{tabular}

$\mathrm{F}$ value $=20.923 ; P>\mathrm{F}=0.0001 ; \mathrm{R}^{2}=0.790 ; \mathrm{R}=0.889 ;$ Adjusted $\mathrm{R}^{2}=0.752$ 
Properties of partial pure B. licheniformisALW1 keratinase

Effect of $p H$

The results in Fig. 5A showed that the partial pure $B$. licheniformis ALW1 keratinase was optimum at $\mathrm{pH}$ 8.5. Lateef et al. [32] reported that most of keratinases are active in neutral to alkaline conditions ranged from $\mathrm{pH} 7.0$ to $\mathrm{pH}$ 9.5. On the other hand Mitsuiki et al. [33] reported that some keratinases were optimum at $\mathrm{pH}$ 12-13. However, the alkaline conditions lead to breaking of disulfide bonds for rapid keratin degradation [9].

\section{Effect of temperature}

The effect of the reaction temperature was investigated in a temperature range from 40 to 80 (Fig. 5A). The optimum temperature was found to be $70^{\circ} \mathrm{C}$ with $50 \%$ increase of activity with respect to control. This result was higher than that reported by Abdel-Naby et al. [13]. Also some authors reported an optimum temperature over $90^{\circ} \mathrm{C}[34]$.

Within the temperature range $50-65^{\circ} \mathrm{C}$ the activation energy (Ea) of Bacillus licheniformis ALW1 keratinase recorded $25.37 \mathrm{kjmol}^{-1}$ (Fig. 5B). This result was lower than that obtained by
Abdel Naby et al.[13] (24 $\left.\mathrm{kJmol}^{-1}\right)$, HernándezMartínez et al.[35] (62 $\left.\mathrm{kJ} \mathrm{mol}^{-1}\right)$. The low value of Ea means low energy needs to make enzyme substrate binding (ES), accordingly the previous result is urgently demanded in industrial application due to cost reduction.

\section{Effect of substrate concentration}

The effect of the substrate concentrations on the rate of its hydrolysis by partial pure keratinase at optimum conditions $\left(\mathrm{pH} 8.5\right.$ and $\left.70^{\circ} \mathrm{C}\right)$ was investigated and indicated that the optimum activity was at $0.7 \%$ substrate concentration. To apply Lineweaver Bulk plot equation, the reciprocal of substrate concentration and specific activity were plotted (Fig. 6). The value of $K_{m}$ was calculated to be $2.45 \mathrm{mg} / \mathrm{mL}$ which is lower than the reported values of B. pumilus $\mathrm{FH} 9,5.55 \mathrm{mg} / \mathrm{ml}$ and that for halophilic bacteria, $16.6 \mathrm{mg} / \mathrm{ml}[13]$. The low $k_{m}$ means high affinity of substrate to make enzyme substrate complex. The value of $V_{\max }$ was calculated to be $2272.7 \mathrm{U} / \mathrm{mg}$ protein which was known as the maximum velocity which theoretically suggested that the enzyme amount participated in the reaction. Also, the value of $V_{\max } / K_{m}(925.9 \mathrm{U}$ mg protein ${ }^{-1} / \mathrm{mg} \mathrm{ml}^{-1}$ ) was higher than the observed ratio (562.79) for $A$. niger protease [36].

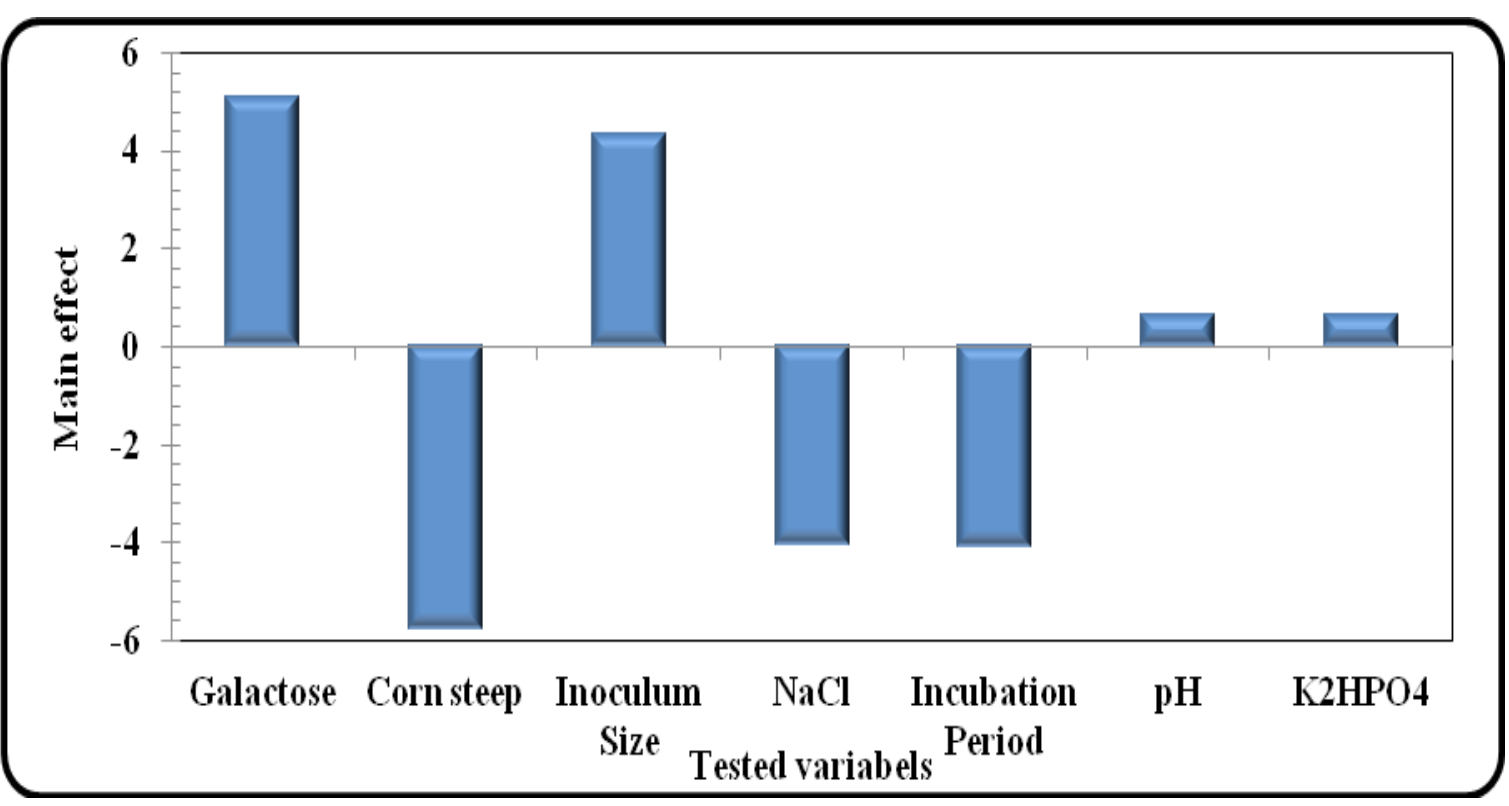

Fig. 2. Main effects of independent variables on Keratinase producution by Bacillus licheniformis ALW1 according to the results of the PBD. 

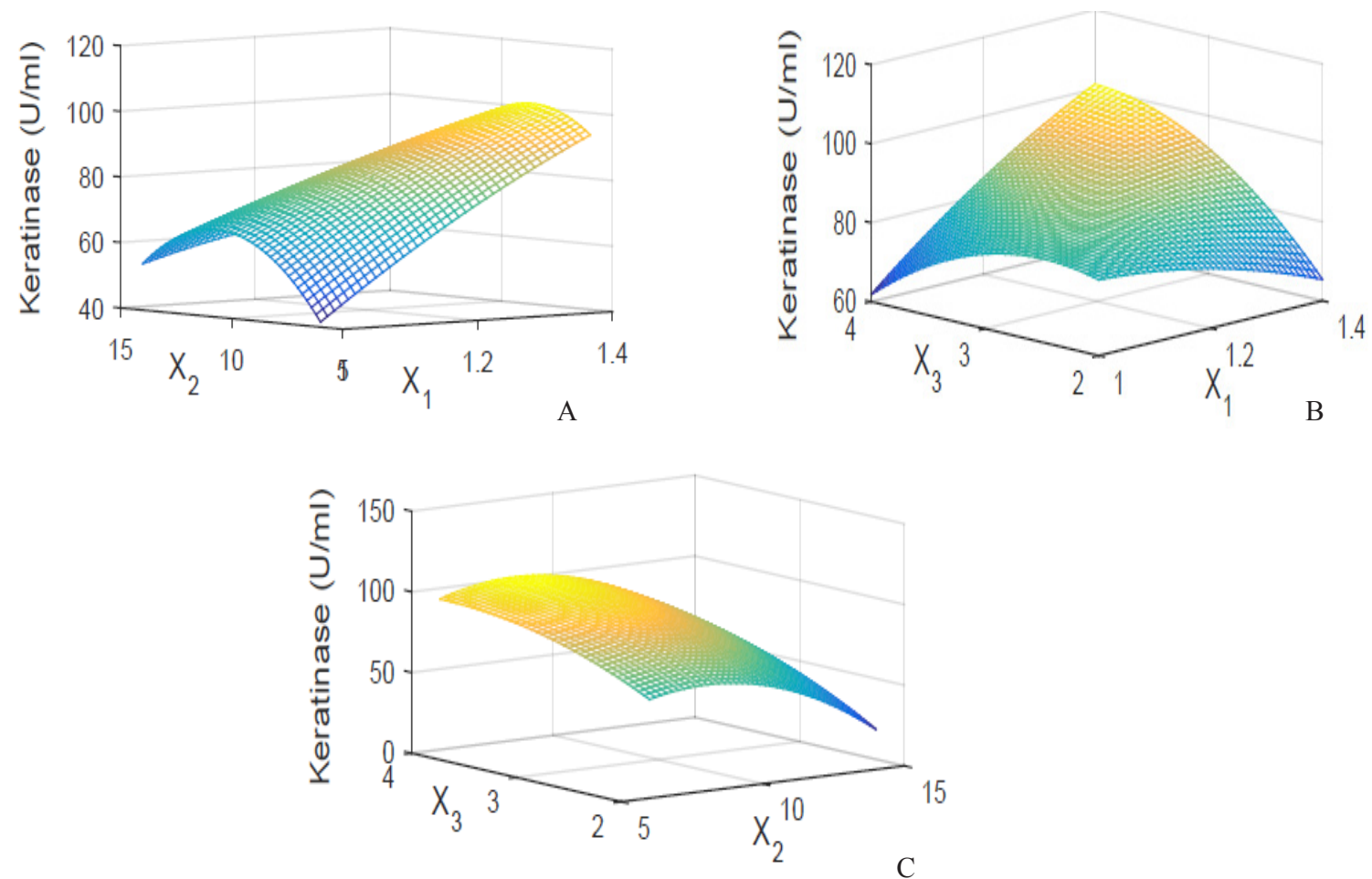

Fig. 3. Response surface plot showing the interactive effects of different concentrations of galactose and CSL at inoculum size $=4 \mathrm{~mL}(\mathrm{~A})$, inoculum size and different concentrations of galactose at CSL $=8.6 \mathrm{~g} / \mathrm{L}(\mathrm{B})$ and inoculum size and different concentrations of CSL at galactose $=1.4 \mathrm{~g} / \mathrm{L}(\mathrm{C})$ on keratinase production by B. licheniformis ALW1.

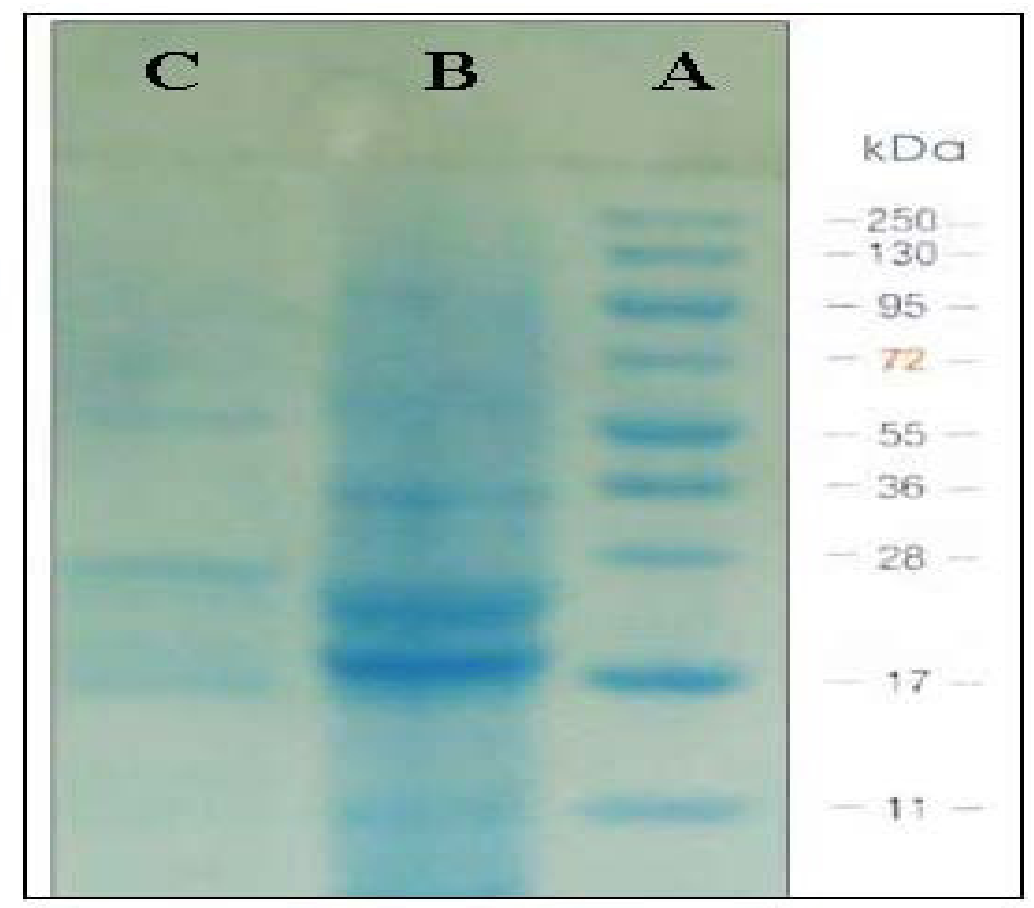

Fig. 4. SDS-PAGE of B. licheniformis ALW1 keratinase. Lane A: MW marker, lane B: crude keratinase (specific activity: $31.5 \mathrm{U} / \mathrm{mg}$ ) and lane $\mathrm{C}$ : partially purified keratinase by $60-70 \%$ acetone (specific activity: 785.6 $\mathbf{U} / \mathbf{m g})$. 


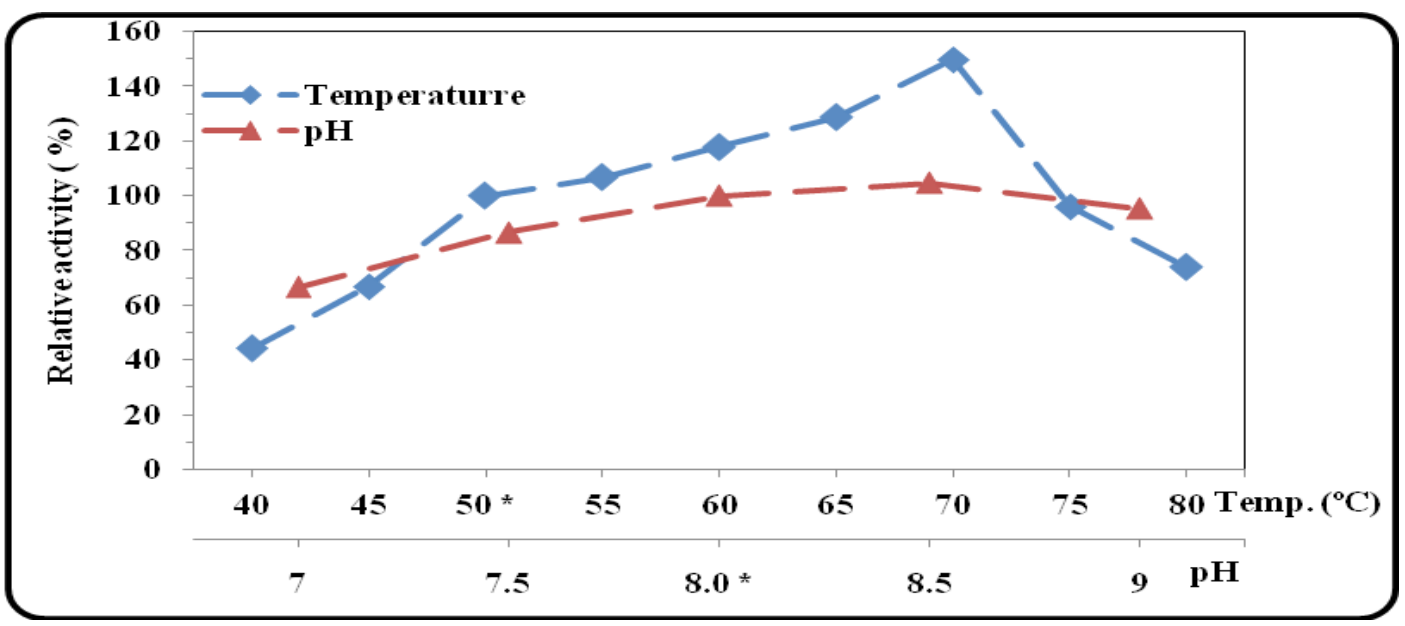

Fig. 5A. Effect of reaction $\mathrm{pH}$ and temperature on the B. licheniformis ALW1 P.P. keratinase activity.

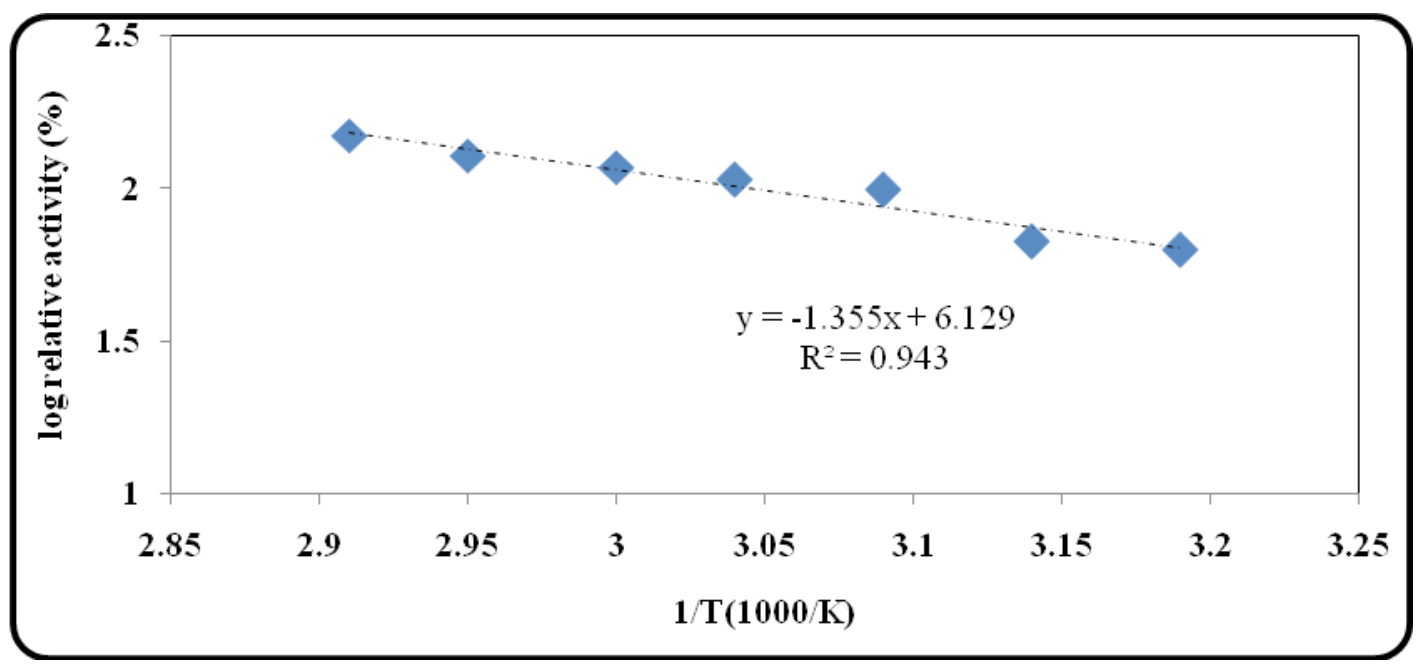

Fig. 5B. Arrhenius plot to calculate the activation energy of the B. licheniformis ALW1 P.P. keratinase

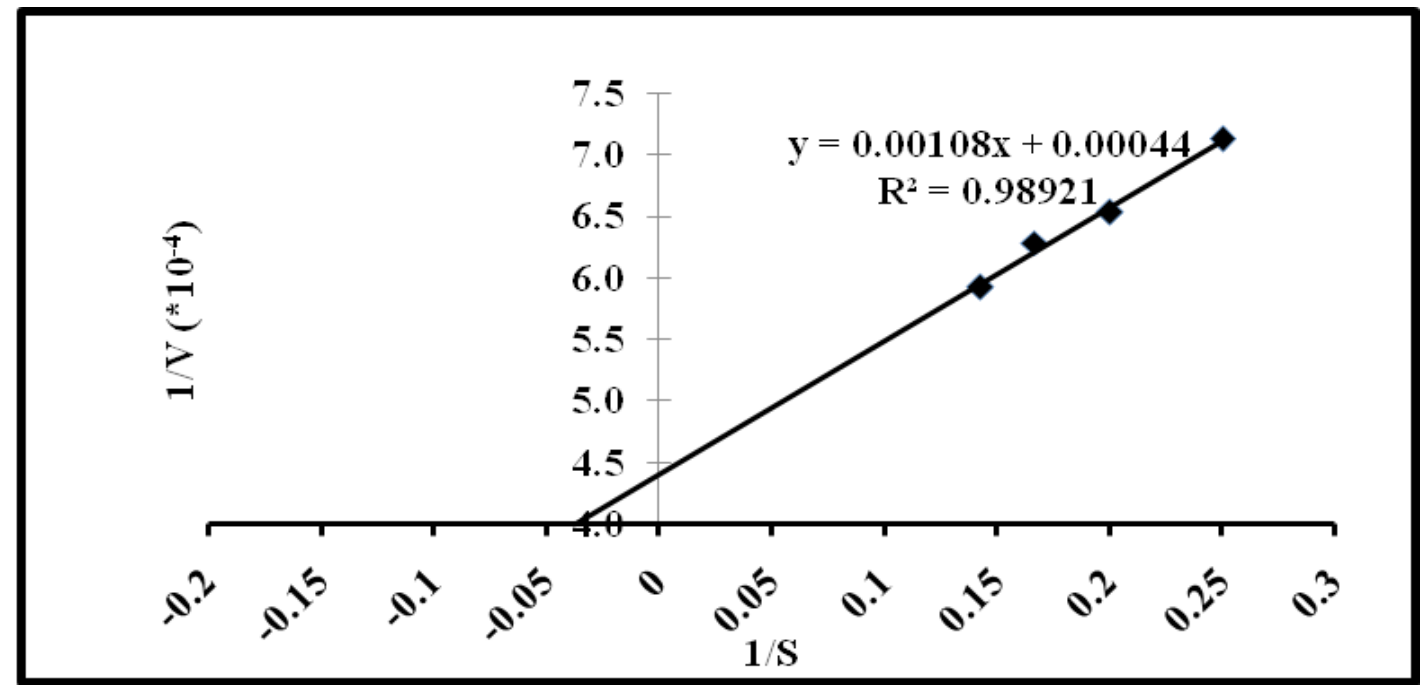

Fig. 6. Lineweaver Bulk plots to measure Michaelis-Menten constant ( $\mathrm{Km})$ and maximum reaction rate (Vmax) and specificity constant $(\mathrm{Vmax} / \mathrm{Km})$ values of partial pure keratinase. 


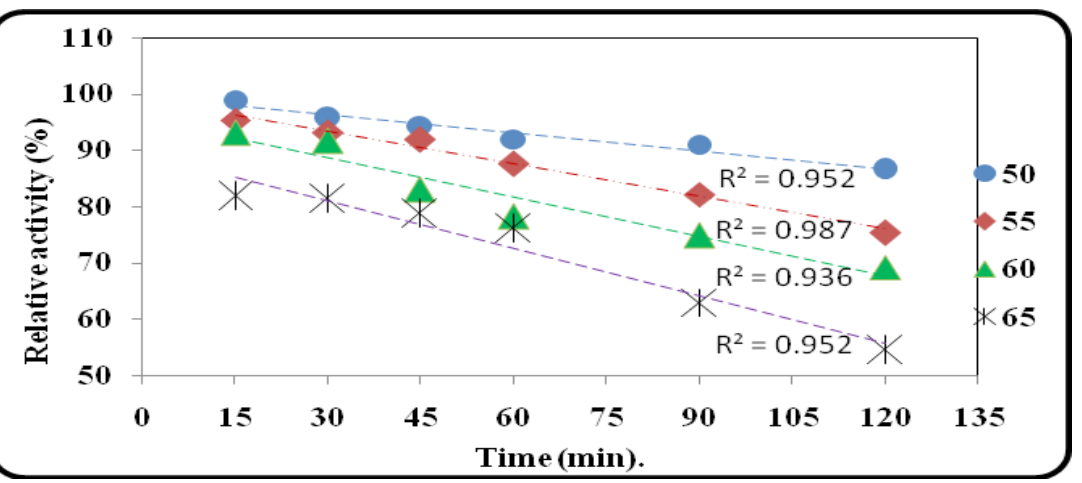

Fig. 7A. Thermal stability profile of B. licheniformis ALW1 P.P.keratinase.

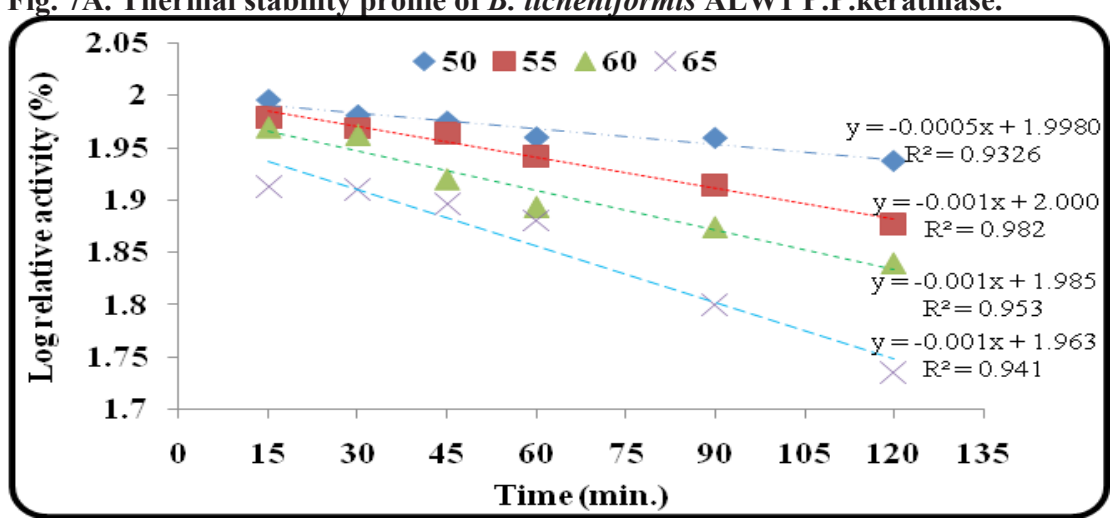

Fig. 7B. First order of thermal deactivation of the B. licheniformis ALW1 keratinase

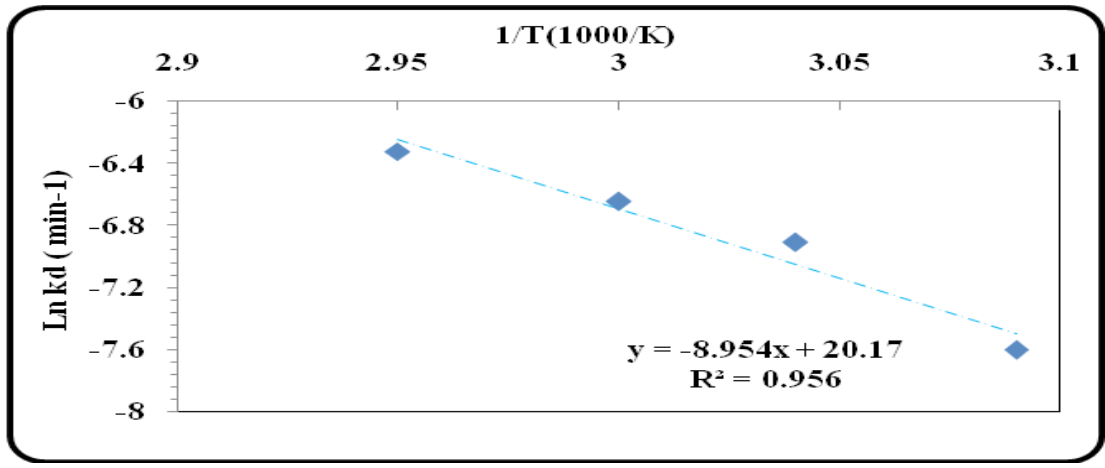

Fig. 7C. Arrhenius plot to calculate activation energy for denaturation (Ed).

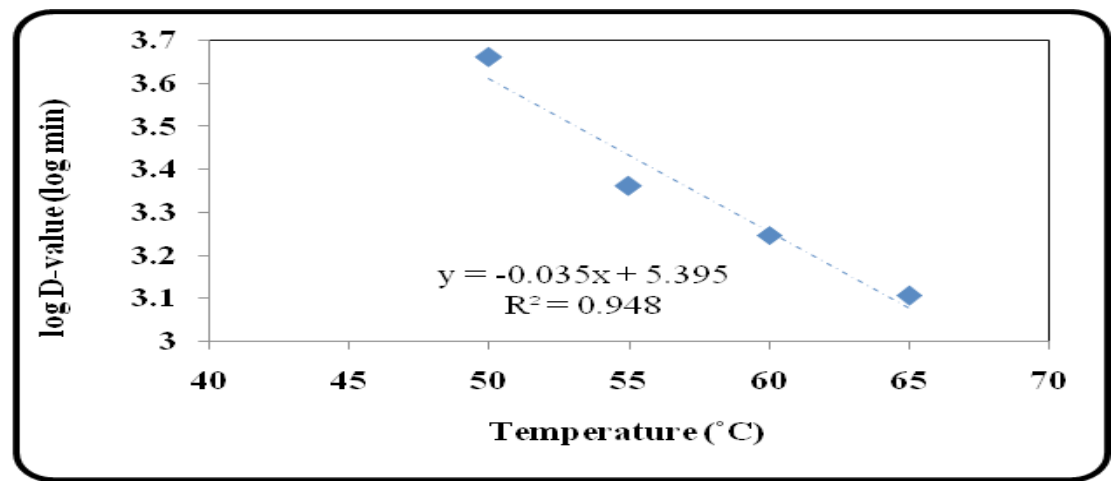

Fig. 7D. Temperature dependence of the decimal reduction of the enzyme. 


\section{Determination of thermal stability}

The thermal stability means the enzyme ability to protect their molecules against the harsh condition. The thermal stability profile (Fig. 7) was studied in the absence of substrate, aiming to evaluate the enzyme denaturation starting point. The results referred to the importance of the substrate in enzyme stability. Although the enzyme achieved its maximum activity at $70^{\circ} \mathrm{C}$ as mentioned above, its original activity reduced about $18 \%$ and $45 \%$ at $65^{\circ} \mathrm{C}$ after 15 and 120 minutes of incubation respectively. The energy of activation for irreversible thermal inactivation $\left(\mathrm{E}_{\mathrm{d}}\right)$ was calculated to be $73 \mathrm{~kJ} \mathrm{~mol}^{-1}$. This result was near to $B$. pumilus FH9 keratinase $\mathrm{E}_{\mathrm{d}}\left(73.38 \mathrm{~kJ} \mathrm{~mol}^{-1}\right)$ [13]. The half-life $\left(t_{1 / 2} \mathrm{~min}.\right)$ was calculated to be $1380,690,530,383$ at 50 , $55,60,65^{\circ} \mathrm{C}$. The enzyme long age is one of the important criteria demanded in industrial applications. Also, $D$ values recorded 4600 , $2300,1769,1277 \mathrm{~min}$. at $50^{\circ} \mathrm{C}, 55^{\circ} \mathrm{C}, 60^{\circ} \mathrm{C}$, $65^{\circ} \mathrm{C}$ respectively. Accordingly, the study of thermodynamic and kinetic parameters was an essential step to evaluate the efficiency of $B$. licheniformis ALW1 keratinase.

\section{Thermodynamic studies}

The study of thermodynamic parameters considers as an important step to evaluate the enzyme capability for application. Within this context, different thermodynamic parameters were determined. Such as, the changes in Gibbs free energy $\left(\Delta G^{\circ}\right)$, enthalpy $\left(\Delta H^{\circ}\right)$ and entropy $\left(\Delta S^{\circ}\right)$ of activation during the thermal enzyme denaturation. In this study the enthalpy results were $70.21 \mathrm{kJmol}^{-1}$, $70.17 \mathrm{kJmol}^{-1}, 70.13 \mathrm{kJmol}^{-1}$ and $69.71 \mathrm{kJmol}^{-1}$ at $50,55,60$ and $65^{\circ} \mathrm{C}$ respectively. This result was about 3 fold higher than $B$. pumilus keratinase FH9 enthalpy [13]. The high value of enthalpy $\Delta H^{\circ}$ means more energy was required for enzyme denaturation [37]. Also, the results pointed to a slight decrease in $\Delta H^{\circ}$ by the temperature elevation and accordingly, margin less energy was required for enzyme unfolding. $\Delta G^{\circ}$ Gibbs free energy recorded approximately, no change between 50$55^{\circ} \mathrm{C}\left(191.49,191.84 \mathrm{kJmol}^{-1}\right.$ respectively) (Table $5)$. This result could interpret the gradual loss in activity from $\left(50-55^{\circ} \mathrm{C}\right.$ at different time intervals) then the $\Delta G^{\circ}$ was elevated to 193.31 and 212.86 $\left(\mathrm{kJmol}^{-1}\right)$ at 60 and $65^{\circ} \mathrm{C}$ respectively. The increase in $\Delta G^{\circ}$ with the increase in temperature worked as barrier in limiting the denaturation process [38]. Also, the negative entropy $\Delta S^{\circ}$ means that the enzyme was in more order state. Where, the Egypt.J.Chem. 61, No. 4 (2018) enzyme structure unfolding was accompanied by an increase in entropy[37].

Effect of various inhibitors, reducing agents, detergents, organic solvents and metal ions on keratinase activity

The effect of PMSF and EDTA on the activity of the partially pure enzyme was investigated. The results indicated that the enzyme activity was partially inhibited by PMSF to $40.6 \%$ and EDTA to $65.5 \%$ (Table 6 ) which indicated that partial pure keratinase could be a mixture of serine and metalloproteases. Other researchers also indicated the presence of keratinolytic activity produced from combined action of serine and metalloproteases [39, 40, 41].

Reducing agents, such as 2-Mercaptoethanol, $\mathrm{Na}_{2} \mathrm{SO}_{3}$ and cysteine were used and observed to have significant positive effect on keratinase activity. The action of reducing agents was done by facilitating the enzyme work on the substrate (after cleavage of cysteine bridges in the substrate) rather than direct effect as keratinase activator $[42,43]$.

Exposure of enzymes to some types of solvents, surfactants or salts could lead to enzyme inactivation as a result of denaturation, aggregation, coagulation or autolysis of the enzyme [44].

The effects of several metal ions on the partial pure keratinase indicated that almost all assayed metal ions were significantly increase keratinolytic activity. The highest two salts caused significant increases of the relative activity were $\mathrm{CaCl}_{2}$ and $\mathrm{MgSO}_{4}$. The inhibitory effect of metal ions was only recorded for $\mathrm{HgCl}_{2}, \mathrm{CoCl}_{2} \cdot 6 \mathrm{H}_{2} \mathrm{O}$ and $\mathrm{ZnCl}_{2}$ with relative activity of 5.8, 70.9 and $59.2 \%$ respectively with respect to control. Our results agree with what was reported by Benkiar et al. [45] and Jaouadi et al. [46]. Where the keratinase was inhibited strongly by $5 \mathrm{mM}$ of $\mathrm{Hg}^{2+}$ and moderately by $\mathrm{Zn}^{2+}$ ions while $\mathrm{Ca}^{2+}$ and $\mathrm{Mg}^{2+}$ ions were totally activated the enzyme.

The inhibitory effect of $\mathrm{Zn}^{2+}$ on some metalloproteases may be a result of bridges formation with the catalytic zinc ions at the active site of the enzyme [47]. Also $\mathrm{Hg}^{2+}$ was classified as a strong enzyme inhibitor because it had high affinity to react with tryptophan residues, carboxyl or thiol groups at or near the active site of the enzyme [48].

Bridges formed by $\mathrm{Ca}^{2+}$ and $\mathrm{Mg}^{2+}$ ions played an important role to maintain the specific active conformation of the enzyme, which could protect 
the enzyme against thermal denaturation and stimulate the enzyme activity [49].

Among all used detergents and organic solvents, DMSO was the best solvent. It increased the keratinolytic activity by $11.4 \%$ over the control. The activating effect could be attributed to the increase of the substrate accessibility to the enzyme [50].

\section{Feather degradation by cell free crude keratinase}

This trial was conducted to improve feather properties by keratinase to be used as organic fertilizer, feedstuff or feed supplement. The results in Fig. 8 indicated that the feather degradation process was a linear function of keratinase units. The percent of hydrolyzing was increased from $48 \%$ to $68.2 \%$ by using $180 \mathrm{U}$ and $680 \mathrm{U}$ respectively. Slightly increase in the hydrolyzing percent was observed by increasing units to about $980 \mathrm{U}$ to get only $74 \%$ degradation percent. Soluble protein released in the degradation broth was frequently increased by increasing keratinase units as a result of feather degradation. This trial represented an ideal method to produce feather meal by crude keratinase as reported by Tiwary and Gupta [8] without need to use reducing agents or reduction- oxidation system of the cells.

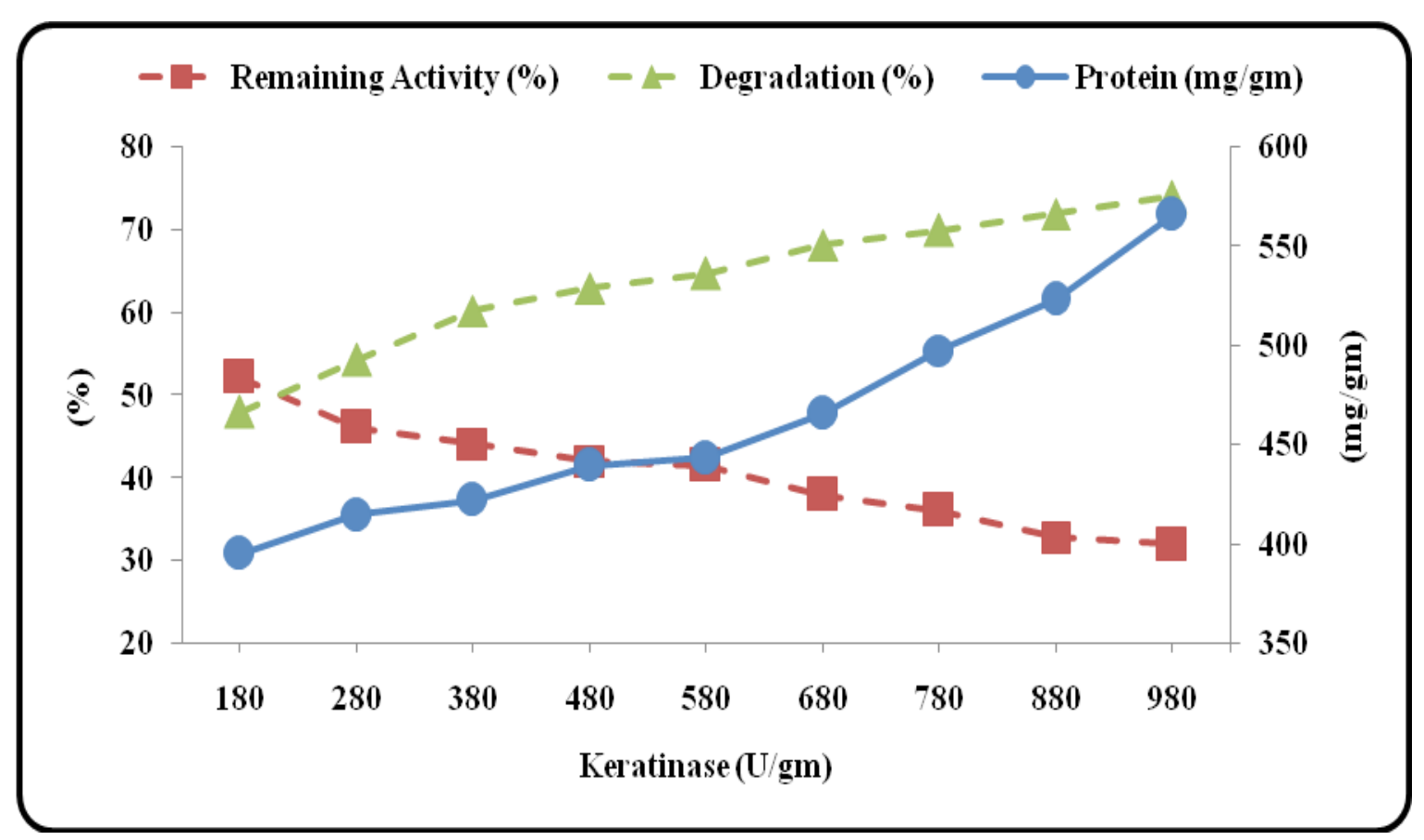

Fig. 8. Feather degradation by cell free crude keratinase

TABLE 5. Thermodynamic parameters for thermal inactivation of B. licheniformis ALW1 keratinase.

\begin{tabular}{ccccc}
\hline $\mathrm{Temp}{ }^{\circ} \mathrm{C}$ & $50{ }^{\circ} \mathrm{C}$ & $55^{\circ} \mathrm{C}$ & $60{ }^{\circ} \mathrm{C}$ & $65^{\circ} \mathrm{C}$ \\
\hline$k_{d}\left(\mathrm{~min}^{-1}\right)$ & 0.0005 & 0.001 & 0.0013 & 0.0018 \\
$t_{l / 2}(\mathrm{~min})$ & 1380 & 690 & 530 & 383 \\
$D$-value (min) & 4600 & 2300 & 1769 & 1277 \\
$\Delta H^{\circ}\left(\mathrm{kJ} \mathrm{mol}^{-1}\right)$ & 70.21 & 70.17 & 70.13 & 69.71 \\
$\Delta G^{\circ}\left(\mathrm{kJmol}^{-1}\right)$ & 191.49 & 191.84 & 193.31 & 212.86 \\
$\Delta S^{\circ}\left(\mathrm{kJmol}^{-1}\right)$ & -375.48 & -370.94 & -369.9 & -373.76 \\
\hline
\end{tabular}


TABLE 6. Effect of various additives on the activity of the P.P. keratinase.

\begin{tabular}{|c|c|c|}
\hline $5 \mathrm{mM}$ & Relative activit & $(\%)$ \\
\hline Control & 100.0 & \pm 3.2 \\
\hline $\mathrm{MnCl}_{2} \cdot 2 \mathrm{H}_{2} \mathrm{O}$ & 107.6 & \pm 1.3 \\
\hline $\mathrm{HgCl}_{2}$ & $5.8^{*}$ & \pm 2.3 \\
\hline $\mathrm{BaCl}_{2} \cdot 2 \mathrm{H}_{2} \mathrm{O}$ & $111.7^{* *}$ & \pm 4.4 \\
\hline $\mathrm{CaCl}_{2}$ & $132.5^{* *}$ & \pm 2.2 \\
\hline $\mathrm{CoCl}_{2} \cdot 6 \mathrm{H}_{2} \mathrm{O}$ & $70.9^{*}$ & \pm 2.1 \\
\hline $\mathrm{CuCl}_{2} \cdot 2 \mathrm{H}_{2} \mathrm{O}$ & $125.4^{* *}$ & \pm 2.2 \\
\hline $\mathrm{MgSO}_{4} \cdot \mathrm{H}_{2} \mathrm{O}$ & $146.0^{* *}$ & \pm 1.0 \\
\hline $\mathrm{ZnCl}_{2}$ & $59.2^{*}$ & \pm 3.4 \\
\hline $\mathrm{NaCl}$ & $122.0^{* *}$ & \pm 2.4 \\
\hline $\mathrm{KCl}$ & $118.6^{* *}$ & \pm 0.6 \\
\hline $\mathrm{LiSO}_{4} \cdot \mathrm{H}_{2} \mathrm{O}$ & $110.8^{* *}$ & \pm 5.0 \\
\hline $\mathrm{Na}_{2}$ EDTA & $65.5^{*}$ & \pm 1.7 \\
\hline PMSF & $40.6^{*}$ & \pm 1.9 \\
\hline SDS & $34.2^{*}$ & \pm 1.5 \\
\hline Tween 80 & 97.0 & \pm 4.9 \\
\hline Glycerin & $78.5^{*}$ & \pm 2.2 \\
\hline Propanol & $86.4^{*}$ & \pm 3.1 \\
\hline DMSO & $111.4^{* *}$ & \pm 0.9 \\
\hline Acetonitrile & $90.1^{*}$ & \pm 1.8 \\
\hline 2-Mercaptoethanol & $117.9^{* *}$ & \pm 2.4 \\
\hline $\mathrm{Na}_{2} \mathrm{SO}_{3}$ & $201.5^{* *}$ & \pm 4.3 \\
\hline Cystein & $112.9^{* *}$ & \pm 1.8 \\
\hline
\end{tabular}

\section{Conclusion}

This work tries to produce and optimize $B$. licheniformis ALW1 keratinase through a Plackett - Burman design (PBD) and Central Composite Design (CCD). The results recorded 1.4-fold increase in the enzyme activity compared to the basal medium. The partially purified enzyme was characterized and a correlation between the thermal stability results and the thermodynamics parameters was done. The study pointed to the rigidity and high thermal stability of the enzyme. Also, the effects of metals ions, detergents, organic solvents, and reducing agent in the enzyme activity were tested. The results gave us explanation about the enzyme structure and the role of the tested substances in activating and inhibiting of the enzyme. Finally, the enzyme had efficiency in hydrolyzing the poultry feather. From the previous results it could be concluded that $B$. licheniformis ALW1 keratinase could be used in different industrial aspects.

\section{Acknowledgments}

Financial support and sponsorship: The authors thank National Research Centre for supporting this work. The manuscript was funded by the project NO.10050305."The authors declare no conflict of interest".

\section{References}

1. Chaturvedi V., Bhange K., Bhatt R. and Verma P., Production of kertinases using chicken feathers as substrate by a novel multifunctional strain of Pseudomonas stutzeri and its dehairing application. Biocatalysis and Agricultural Biotechnology, 3, 167-174 (2014).

2. Sawant R. and Nagendran S., Protease: an enzyme with multiple industrial applications. World Journal of Pharmacy and Pharmaceutical Sciences, 3(6), 568-579 (2014).

3. Singh R., Kumar M., Mittal A. and Mehta P.K., Microbial enzymes: industrial progress in $21^{\text {st }}$ century. 3 Biotech, 6 (2), 174 (2016).

4. Cedrola S.M., de Melo A.C., Mazotto A.M., Lins U., Zingali R.B., Rosado A.S., Peixoto R.S. and Vermelho A.B., Keratinases and sulfide from Bacillus subtilis SLC to recycle feather waste. World Journal of Microbiology and Biotechnology, 28, 1259-1269 (2012).

5. Mazotto A.M., de Melo A.C., Macrae A., Rosado A.S., Peixoto R., Cedrola S.M., Couri S., Zingali R.B., Villa A.L., Rabinovitch L., Chaves J.Q. and Vermelho A.B., Biodegradation of feather waste by extracellular keratinases and gelatinases from Bacillus sp. World Journal of Microbiology and Biotechnology, 27, 1355-1365 (2011).

6. Abdel-Fattah Y.R., El-Enshasy H.A., Soliman N.A. and El-Gendi H., Bioprocess development for production of alkaline protease by Bacillus pseudofirmus Mn6 through statistical experimental designs. Journal of Microbiology and Biotechnology, 19 (1), 1-9 (2009).

7. Awad G.E., Esawy M.A., Salam W.A., Salama B.M., Abdelkader A.F. and El-diwany A., Keratinase production by Bacillus pumilus GHD in solid-state fermentation using sugar cane bagasse: optimisation of culture conditions using a Box-Behnken experimental design. Annals of Microbiology, 61(3), 663-672 (2011).

8. Tiwary E. and Gupta R., Rapid conversion of 
chicken feather to feather meal using dimeric keratinase from Bacillus licheniformis ER-15. Journal of Bioprocessing and Biotechniques, 2(4), 1-5 (2012).

9. Mazotto A.M., Couri S., Damaso M.C. and Vermelho A.B., Degradation of feather waste by Aspergillus niger keratinases: comparison of submerged and solid-state fermentation. International Biodeterioration and Biodegradation, 85, 189-195 (2013).

10.Yue X.Y., Zhang B., Jiang D.D., Liu Y.J. and Niu T.G., Separation and purification of a keratinase as pesticide against root-knot nematodes. World Journal of Microbiology and Biotechnology, 27, 2147-2153 (2011).

11. Brandelli A., Bacterial keratinases: useful enzymes for bioprocessing agroindustrial wastes and beyond. Food and Bioprocess Technology, 1, 105116 (2008).

12. Silveira S., Gemelli S., Segalin J. and Brandelli A., Immobilization of keratinolytic metalloprotease from Chryseobacteriumsp. strain $\mathrm{kr} 6$ on glutaraldehyde-activated chitosan. Journal of Microbiology and Biotechnology,22, 818-825 (2012).

13. Abdel-Naby M.A., El-Refai H.A. and Ibrahim M.H., Structural characterization, catalytic, kinetic and thermodynamic properties of keratinase from Bacillus pumilusFH9. International Journal of Biological Macromolecules, 105, 973-980 (2017).

14. Silveira S.T., Casarin F., Gemelli S. and Brandelli A., Thermodynamics and kinetics of heat inactivation of a novel keratinase from Chryseobacterium sp. strain kr6. Applied Biochemistry and Biotechnology, 162(2), 548-560 (2010).

15. Saber W.I., El-Metwally M.M. and El-Hersh M.S., Keratinase production and biodegradation of some keratinous wastes by Alternariatenuissima and Aspergillus nidulans. Research Journal of Microbiology, 5, 21-35 (2010).

16. Abdel-fattah A.M., Nashy E.S., Sabiel E.T., Hussien M.M. and Attia A.S., Novel keratinolytic activity of Cyberlindnera fabianii $\mathrm{Nrc3}$ Aza as a plant growth promoting agent (PGPA). International Journal of Applied Sciences and Biotechnology, 3(4), 609-618 (2015).

17. Cai C., Lou B. and Zheng X., Keratinase production and keratin degradation by a mutant strain of Bacillus subtilis. Journal of Zhejiang UniversityScience B, 9(1), 60-67 (2008b).
18. Lowry O.H., Rosebrough N.J., Farr A.L. and Randall R.J., Protein measurement with folin phenol reagent. Journal of Biological Chemistry, 193, 265- 275 (1951).

19. Plackett R.L. and Burman J.P., The design of optimum multi-factorial experiments. Biometrika, 33, 305-325 (1946).

20. Tari C., Genckal H. and Tokatli F., Optimization of a growth medium using a statistical approach for the production of an alkaline protease from a newly isolated Bacillus sp. L21. Process Biochemistry, 41, 659-665 (2006).

21. Adinarayana K., Ellaiah P. Srinivasulu B., Bhavani R. and Adinarayana G., Response surface methodological approach to optimize the nutritional parameters for neomycin production by Streptomyces marinensisunder solid-state fermentation. Process Biochemistry, 38, 1565-1572 (2003).

22. Box G.E., Hunter W.G. and Hunter J.S., Statistics for Experiments. New York: Wile, P. 291-334 (1978).

23. Laemmli U.K., Cleavage of structural proteins during the assembly of the head of bacteriophage T4. Nature, 227(5259), 680-685 (1970).

24. Sivakumar T., Shankar T., Vijayabaskar P. and Ramasubramaman V., Optimization for keratinase enzymes production using Bacillus thuringiensis TS2. Academic Journal of Plant Sciences, 5(3), 102-109 (2012).

25. Ni H., Chen Q., Chen F., Fu M., Dong Y. andCai H., Improved keratinase production for feather degradation by Bacillus Licheniformis ZJUEL31410 in submerged cultivation. African Journal of Biotechnology, 10 (37), 7236-7244 (2011).

26. Jani S.A., Malek S., Patel A., Pathak K. and Baria K., Production of alkaline keratinolytic protease by Bacillus sp. B13 from feather waste. International Journal of Current Microbiology and Applied Sciences, 6(5), 1538 1552 (2017).

27. Bahçeci K.S. and Acar J., Modeling the combined effects of $\mathrm{pH}$, temperature and ascorbic acid concentration on the heat resistance of Alicyclobacillus acidoterrestis. International Journal of Food Microbiology, 120(3), 266273(2007). 
28. Saibabu V., Niyonzima F.N. and More S.S., Isolation, partial purification and characterization of keratinase from Bacillus megaterium. International Research Journal of Biological Sciences, 22(2), 1320 (2013).

29. Tiwary E. and Gupta R., Medium optimization for a novel $58 \mathrm{Kda}$ dimeric keratinase from Bacillus licheniformis ER-15: biochemical characterization and application in feather degradation and dehairing of hides. Bioresource Technology, 101, 6103-6110 (2010).

30. Nayaka S., and Vidyasagar G.M., Purification and characterization of keratinase from hair-degrading Streptomyces albus. International Journal of Bioassays, 2(3), 599-604(2013).

31. Bressollier P., Letourneau F., Urdaci M., and Verneuil B., Purification and characterization of a keratinolytic serine proteinase from Streptomyces albidoflavus. Applied and Environmental Microbiology, 65(6), 2570-2576(1999).

32. Lateef A., Adelere I.A. and Gueguim-Kana E.B., Bacillus safensis LAU 13: a new source of keratinase and its multi-functional biocatalytic applications. Biotechnology and Biotechnological Equipment, 29(1), 54-63(2015).

33.Mitsuiki S., Ichikawa M., Oka T., Sakai M., Moriyama Y., Sameshima Y., Goto M. and Furukawa K., Molecular characterization of a keratinolytic enzyme from an alkaliphilic Nocardiopsis sp. TOA-1. Enzyme and Microbial Technology, 34(5), 482-489 (2004).

34. Friedrich J. and Kern S., Hydrolysis of native proteins by keratinolytic protease of Doratomyces microsporus. Journal of Molecular Catalysis B: Enzymatic, 21(1-2), 35-37(2003).

35. Hernández-Martínez R., Gutiérrez-Sánchez G., Bergmann C.W., Loera-Corral O., RojoDomínguez A., Huerta-Ochoa S. and PradoBarragán, L.A., Purification and characterization of a thermodynamic stable serine protease from Aspergillus fumigatus. Process Biochemistry,46(10), 2001-2006 (2011).

36. de Castro R.J., Ohara A., Nishide T.G., Albernaz J.R., Soares M.H. and Sato H.H., A new approach for proteases production by Aspergillus niger based on the kinetic and thermodynamic parameters of the enzymes obtained. Biocatalysis and Agricultural Biotechnology, 4(2), 199-207 (2015).

37. Nagar S., Mittal A., Kumar D. and Gupta Egypt.J.Chem. 61, No. 4 (2018)
V.K., Production of alkali tolerant cellulase free xylanase in high levels by Bacillus pumilus SV-205. International Journal of Biological Macromolecules, 50, 414-420 (2012).

38. Karam E.A., Wahab W.A., Saleh S.A., Hassan M.E., Kansoh A.L. and Esawy M.A., Production, immobilization and thermodynamic studies of free and immobilized Aspergillus awamori amylase. International Journal of Biological Macromolecules, 102， 694-703 (2017).

39. Cai C.G., Chen J.S., Qi J.J., Yin Y. and Zheng X.D., Purification and characterization of keratinase from a new Bacillus subtilis strain. Journal of Zhejiang University-Science B, 9(9), 713-720 (2008a).

40. Korkmaz H., Hür H. and Dinçer S., Characterization of alkaline keratinase of Bacillus licheniformis strain HK-1 from poultry waste. Annals of Microbiology, 54(2), 201-211 (2004).

41. Tork S.E., Shahein Y.E., El-Hakim A.E., Abdel-Aty A.M. and Aly M.M., Production and characterization of thermostable metallo-keratinase from newly isolated Bacillus subtilis NRC 3. International Journal of Biological Macromolecules, 55, 169175 (2013).

42. Gupta R. andRamnani P., Microbial keratinases and their perspective applications: an over view. Applied Microbiology and Biotechnology, 70, 2133 (2006).

43. Onifade A.A., Al-Sane N.A., Al-Mussallam A.A. and Al-Zarbam S., Potential for biotechnological application of keratin-degrading microorganisms and their enzymes for nutritional improvement of feathers and other keratins as livestock feed resources. Bioresource Technology, 6, 1-11 (1998)

44. Cavello I.A. and Cavalitto S.F., Kinetic modelling of thermal inactivation of a keratinase from Purpureocillium lilacinum LPSC \# 876 and the influence of some additives on its thermal stability. Applied Biochemistry and Biotechnology,173, 1927-1939 (2014)

45. Benkiar A., Nadia Z.J., Badis A., Rebzani F., Soraya B.T., Rekik H. and Jaouadi B., Biochemical and molecular characterization of a thermo-and detergent-stable alkaline serine keratinolytic protease from Bacillus circulans strain DZ100 for detergent formulations and feather-biodegradation process. International Biodeterioration and Biodegradation, 83, 129-138 (2013).

46. Jaouadi B., Ellouz-Chaabouni S., Rhimi M. and Bejar S., Biochemical and molecular characterization of a detergent-stable serine 
alkaline protease from Bacillus pumilus CBS with high catalytic efficiency. Biochimie, 90, 1291-1305 (2008).

47. Riffel A., Brandelli A., Bellato C.M., Souza G.H., Eberlin M.N. and Tavares F.C., Purification and characterization of a keratinolytic metalloprotease from Chryseobacterium sp. kr6. Journal of Biotechnology, 128, 693-703 (2007).

48. Daroit D.J., Simonetti A., Hertz P.F. and Brandelli A., Purification and characterization of an extracellular beta-glucosidase from Monascus purpureus. Journal of Microbiology and Biotechnology, 18, 933-941 (2008).
49. Corrêa A.P., Daroit D.J. and Brandelli A., Characterization of a keratinase produced by Bacillus sp. P7 isolated from an Amazonian environment. International Biodeterioration and Biodegradation, 64, 1-6 (2010).

50. Yilmaz B., Baltaci M.O., Sisecioglu M. and Adiguzel A., Thermotolerant alkaline protease enzyme from Bacillus licheniformis A10: purification, characterization, effects of surfactants and organic solvents. Journal of Enzyme Inhibition and Medicinal Chemistry, 31(6), 1241-1247 (2016).

(Received 4 / 4/ 2018; accepted 22/ 4 /2018)

\section{تحسين وتوصيف ودراسات ديناميكية حرارية علي الكيراتينيز المنتج من العزلة البكتيرية Bacillus licheniformis ALW1}

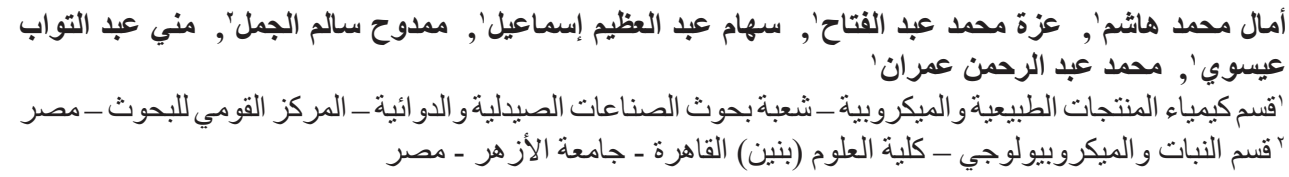

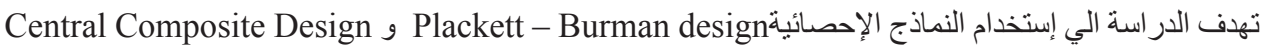

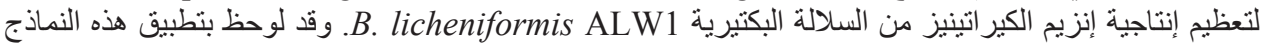

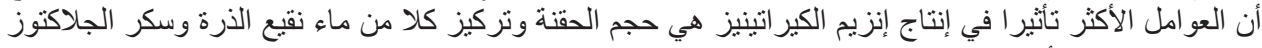

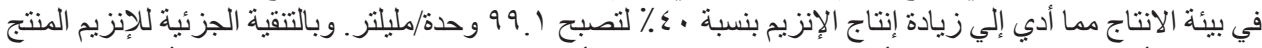

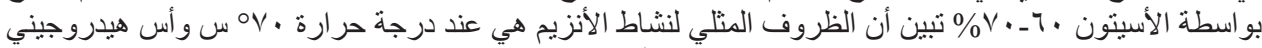

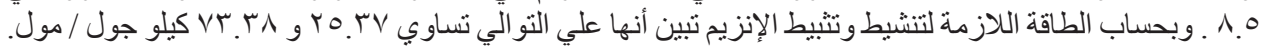

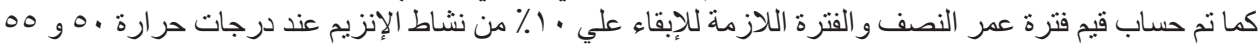

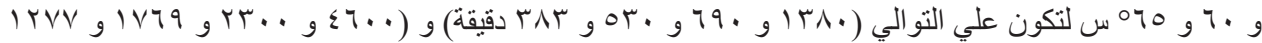

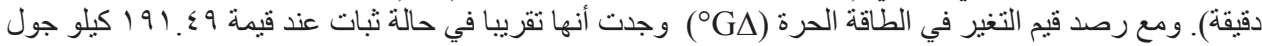

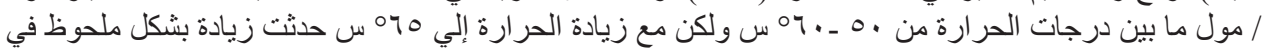

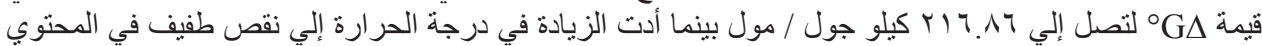

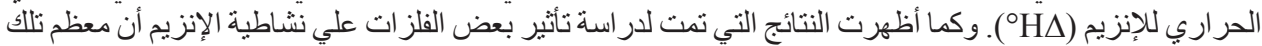

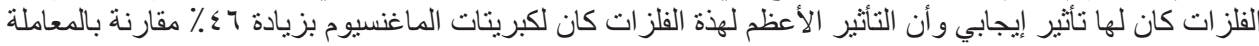

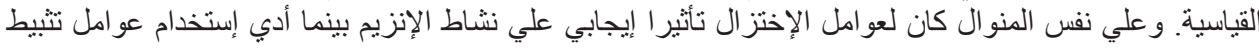

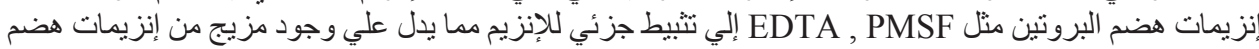

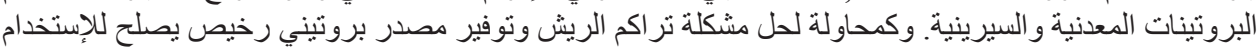

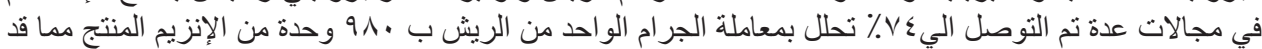
يوفر حلا فاعلا لهذه المشكلة. 